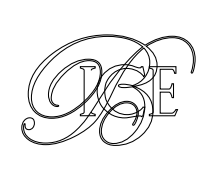

Subdirección General de Estudios y Evaluación de Instrumentos de Política Comercial*

\title{
LAS CARACTERÍSTICAS DE LA EMPRESA EXPORTADORA ESPAÑOLA (2018)
}

El objetivo de este artículo es analizar los rasgos de la empresa exportadora española de mercancías a partir de las estadísticas de comercio exterior por características de la empresa que publican Aduanas y Eurostat. Con ello se pretende conocer mejor la estructura de la base exportadora española y disponer de una referencia válida para el diseño e instrumentación tanto de la política de apoyo a la internacionalización de las empresas como de las propias estrategias comerciales de las mismas. Este análisis descriptivo, principalmente de corte transversal para el año 2018, examina la relevancia de las distintas variables que caracterizan a la empresa, como su tamaño, actividad principal, control de la propiedad, regularidad exportadora o naturaleza de empresas importadoras.

Los últimos datos disponibles en el momento de realizar este artículo corresponden al año 2018, por lo que no se ven afectados ni por el Brexit, que tuvo lugar el 31 de enero de 2020, ni por la pandemia de la COVID-19, efectos que solo podrán ser analizados cuando se publiquen los datos correspondientes a 2020.

Palabras clave: España, comercio exterior, exportación, empresa exportadora, Aduanas, Eurostat, pyme. Clasificación JEL: F14, F23.

\section{Introducción}

El análisis de las características de las empresas españolas exportadoras permite conocer la relevancia que determinadas variables tienen sobre la probabilidad de que una empresa exporte, el valor de sus exportaciones o la regularidad en sus exportaciones y orientar, en consecuencia, la política de apoyo a las

\footnotetext{
* Secretaría de Estado de Comercio. Ministerio de Industria Comercio y Turismo.

Versión de diciembre de 2020.

DOI: https:/doi.org/10.32796/bice.2021.3131.7145
}

exportaciones. El objeto de este trabajo es realizar este estudio para el año 2018 a partir de las estadísticas que publica el Departamento de Aduanas e Impuestos Especiales de la Agencia Tributaria (Aduanas en adelante) y comparar las características de las empresas españolas exportadoras con las de sus homólogas comunitarias con los datos de Eurostat ${ }^{1}$. El análisis se centra en las características $D$

\footnotetext{
1 Aduanas en «Comercio exterior por características de la empresa» y Eurostat en «International trade in goods - trade by enterprise characteristics (TEC) (ext_tec)».
} 
de las empresas exportadoras, pero el lector interesado puede obtener de estas dos fuentes datos análogos correspondientes a las empresas importadoras.

Para caracterizar a las empresas que realizan la actividad comercial con el exterior, Aduanas cruza anualmente los datos de comercio exterior por operador con los del Directorio Central de Empresas (DIRCE) del Instituto $\mathrm{Na}$ cional de Estadística (INE), lo que permite explotar sus variables de clasificación, como la actividad económica principal o el tamaño, entre otras. Estas estadísticas enriquecen el análisis de flujos, la composición sectorial y la orientación geográfica de las exportaciones de los datos mensuales de Aduanas disponibles en la web de Datacomex (http://datacomex.comercio.es/), de la Secretaría de Estado de Comercio (SEC en adelante). Así mismo, el Informe Mensual de Comercio Exterior, también de la SEC, presenta con gran detalle la distribución geográfica y por productos de los flujos del comercio exterior de bienes de España.

En el epígrafe 2 se examinan los distintos conceptos de exportador o empresa exportadora española que pueden definirse a partir de estas fuentes. Esta visión global permite enmarcar el análisis que se efectúa en los epígrafes 3 a 8 específicamente con los datos de comercio declarado realizado por los exportadores que cruzan con el DIRCE (empresas exportadoras DIRCE, en adelante).

En los epígrafes 3 a 8 se analizan los rasgos de las empresas exportadoras DIRCE, atendiendo a diferentes variables de clasificación y, cuando haya posibilidad, a cruces entre ellas. Estas variables son: el tamaño, definido según el número de asalariados, la actividad principal de la empresa según la Clasificación Nacional de Actividades Económicas (CNAE), los tramos de exportación, la concentración de las exportaciones, la regularidad y, por último, los destinos geográficos por zonas de intercambio y número de destinos.

El análisis se complementa, en el epígrafe 9, con una comparativa internacional analizando los datos de Eurostat, tanto para España como para los principales países exportadores de la UE. Estos datos presentan algunas diferencias metodológicas significativas con respecto a los datos de Aduanas, que se presentan en detalle en el anexo metodológico al final de este artículo.

Con los datos de Eurostat se realizará, en primer lugar, una comparativa por países de la distribución del número de empresas exportadoras y el valor de las exportaciones por tamaño de la empresa, para posteriormente y, a partir de estos datos, calcular la propensión exportadora. Otras dimensiones analizadas serán la concentración, el tipo de propiedad de la empresa o si las empresas que exportan son al mismo tiempo importadoras.

Finalmente, en el último epígrafe se presentarán las principales conclusiones extraídas.

El estudio es esencialmente de corte transversal con los datos de 2018 , si bien en la mayor parte de los cuadros se presentan también datos de otros años y la tasa de variación con respecto al año anterior. El análisis longitudinal a medio plazo debe ser tomado con cautela debido a la ruptura de la serie en 2015, derivada de la elevación del umbral de exención.

\section{Visión general}

Con el objetivo de facilitar al lector la comprensión de los datos que se muestran, en este apartado se presentan, desde una perspectiva global, los distintos conceptos $D$ 
de exportador o empresa exportadora que pueden definirse a partir de las fuentes empleadas y se explican las principales diferencias entre ellos. Así, se facilita que el lector comprenda las diferencias que se pueden observar entre estos datos y otros empleados habitualmente en el estudio de los flujos de comercio internacional y sea consciente del alcance y las limitaciones que puede tener este análisis.

El de exportador de comercio total es el concepto más amplio que se obtiene directamente de las estadísticas de Aduanas. Este concepto incluye a cualquier operador, sea o no empresa, que haya realizado alguna operación de exportación en el año correspondiente. Bajo esta definición en 2018 hubo en España 257.997 exportadores (Gráfico 1, Cuadros 1A y 1B). No obstante, se trata de una cifra poco relevante para el análisis de las características de las empresas que exportan, ya que incluye a un elevado número de operadores, que no son necesariamente empresas y que presentan, además, un volumen de comercio muy poco relevante. Muestra de ello es el fuerte incremento en el número de exportadores fuera de la UE en $2018(28,4 \%)$, donde no existe un umbral que exima de la declaración. Al cruzar con el DIRCE, este incremento se reduce al 3,2\%. Este hecho indica que buena parte del incremento se ha debido al aumento del número de particulares que exportan a destinos no comunitarios $\mathrm{y}$, por tanto, están sujetos a la obligación de realizar declaraciones de exportación.

El de exportador del comercio declarado es un concepto más restrictivo, aunque también incluye operadores que no pueden considerarse empresas. En 2018 hubo 203.610 exportadores de comercio declarado, que exportaron por valor de 284.720 millones de euros, aproximadamente el $97,5 \%$ de las exportaciones totales (292.254 millones de euros). Aduanas obtiene estos datos directamente de las declaraciones de los exportadores, ya sea a través de las declaraciones aduaneras (DUA) en el comercio extracomunitario, ya sea por medio de las declaraciones estadísticas Intrastat en el intracomunitario. La diferencia entre el comercio declarado y el comercio total es la parte del comercio intracomunitario realizada por operadores no obligados a la presentación de las declaraciones Intrastat por no superar el umbral de exención ${ }^{2}$. Gracias a estas declaraciones se conocen con detalle los importes, los productos exportados, así como el destino concreto de los mismos. Estos datos prácticamente coinciden en valor con los que publica la SEC en el Informe Mensual de Comercio Exterior, que incluye un apartado de exportadores, y en la web de Datacomex (DataEmpresas en http://datacomex.comercio.es/), así como en el informe Perfil de la Empresa Exportadora Española del ICEX.

Para calcular el comercio total, Aduanas estima el valor no declarado a partir de las declaraciones del IVA. De este comercio intracomunitario no declarado no se puede conocer ni el destino ni el producto comercializado. En 2018, Aduanas estimó la existencia de 98.734 operadores bajo umbral que exportaron a la UE por valor de 7.535 millones. Así, aunque el número de operadores bajo umbral es elevado, el importe de las operaciones que realizan es poco significativo, ya que apenas representa el $\triangleright$

\footnotetext{
2 En 2018 el umbral de exención para España se situó en los 400.000 euros de exportaciones a la Unión Europea en el año anterior o a lo largo del año de referencia. Solo los operadores que lo superen estarán obligados a presentar las declaraciones Intrastat; por debajo de ese valor están exentos. Este umbral ha permanecido fijo desde 2015, mientras que entre 2008 y 2014 se situó en los 250.000 euros. Este salto ha supuesto una ruptura de la serie en 2015, por lo que las comparativas con años precedentes se deben tomar con mucha precaución.
} 


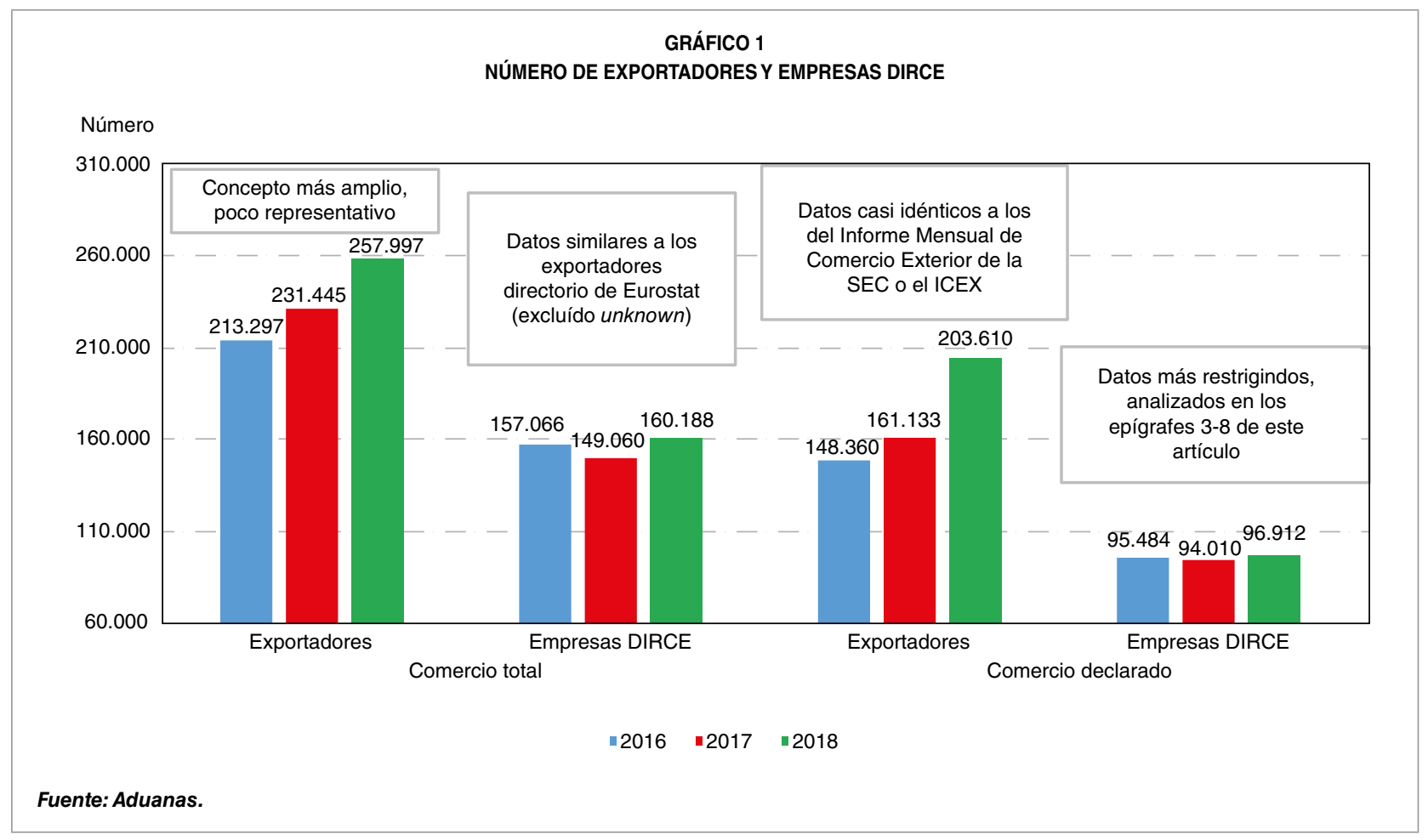

$2,6 \%$ de las exportaciones totales. De estos operadores bajo umbral, 44.347 habían exportado también fuera de la UE, exportaciones que sí fueron declaradas y, por tanto, contabilizadas en el comercio declarado.

Para obtener una mejor aproximación al concepto de empresa exportadora, Aduanas cruza los operadores de comercio exterior del comercio declarado con el directorio central de empresas del INE (DIRCE), que incluye variables de clasificación como la actividad económica principal o el tamaño. Los operadores que están incluidos en el ámbito poblacional del DIRCE son empresas en sentido amplio ${ }^{3}$.

Se obtiene así el concepto de empresas exportadoras DIRCE de comercio declarado. Estas empresas representan un elevado porcentaje del comercio declarado (y también del

3 Unidades incluidas en el DIRCE que realizan una actividad económica pero no tienen necesariamente forma jurídica de empresa (p. ej.: autónomos). comercio total). Así, en 2018 las 96.912 empresas exportadoras de comercio declarado que cruzaron con el DIRCE exportaron por valor de 259.749 millones de euros. Aunque supusieron únicamente el $47,6 \%$ de los exportadores de comercio declarado, su importancia en términos de valor exportado es muy superior, un 91,2\% (Gráfico 2).

Aduanas analiza las características de las empresas españolas exportadoras o importadoras a partir de las empresas de comercio declarado DIRCE, que permiten realizar un análisis más rico. Todo el análisis de los epígrafes 3 a 8 versará sobre las empresas exportadoras DIRCE de comercio declarado.

Un concepto adicional es el de exportador regular (o estable, en terminología de Aduanas). Se define como exportador regular aquel que ha exportado en el año de referencia y en cada uno de los tres años precedentes. En los epígrafes que siguen se hará especial referencia a las características de los exportadores $\square$ 
CUADRO 1A

NÚMERO DE EXPORTADORESY EMPRESAS EXPORTADORAS DIRCE DE COMERCIO DECLARADOY TOTAL

\begin{tabular}{|c|c|c|c|c|c|c|c|c|c|c|}
\hline \multirow[b]{2}{*}{ Concepto } & \multicolumn{10}{|c|}{ Exportadores (número) } \\
\hline & 2010 & 2011 & 2012 & 2013 & 2014 & 2015 & 2016 & 2017 & 2018 & $\begin{array}{c}\text { Variación } \\
2018 / 2017(\%)\end{array}$ \\
\hline Extra UE (comercio declarado) & 97.607 & 111.784 & 125.995 & 139.072 & 135.520 & 135.372 & 136.470 & 149.273 & 191.624 & 28,4 \\
\hline UE (comercio declarado). & 29.435 & 29.870 & 31.088 & 32.662 & 33.123 & 31.649 & 31.449 & 31.161 & 31.273 & 0,4 \\
\hline Comercio declarado ........... & 109.363 & 123.128 & 137.528 & 151.160 & 147.845 & 147.334 & 148.360 & 161.133 & 203.610 & 26,4 \\
\hline UE (comercio estimado) .................... & nd & nd & nd & nd & 80.185 & 87.938 & 90.626 & 96.015 & 98.734 & 2,8 \\
\hline Comercio total $\ldots$ & nd & nd & 181.447 & 197.707 & 204.574 & 209.067 & 213.297 & 231.445 & 257.997 & 11,5 \\
\hline \multirow[b]{2}{*}{ Concepto } & \multicolumn{10}{|c|}{ Empresas exportadoras DIRCE (número) } \\
\hline & 2010 & 2011 & 2012 & 2013 & 2014 & 2015 & 2016 & 2017 & 2018 & $\begin{array}{c}\text { Variación } \\
2018 / 2017(\%)\end{array}$ \\
\hline Extra UE (comercio declarado) .... & 62.880 & 74.698 & 82.195 & 85.713 & 85.849 & 86.979 & 86.961 & 85.409 & 88.136 & 3,2 \\
\hline UE (comercio declarado) ... & 26.142 & 27.001 & 28.233 & 29.264 & 29.514 & 27.620 & 27.272 & 27.133 & 27.273 & 0,5 \\
\hline Comercio declarado DIRCE .. & 72.047 & 83.725 & 91.409 & 95.139 & 95.328 & 95.703 & 95.484 & 94.010 & 96.912 & 3,1 \\
\hline UE (comercio estimado) ... & nd & nd & nd & nd & nd & 84.412 & 87.064 & 80.580 & 93.690 & 16,3 \\
\hline Comercio total DIRCE. & nd & nd & nd & nd & nd & 154.174 & 157.066 & 149.060 & 160.188 & 7,5 \\
\hline \multirow[b]{2}{*}{ Concepto } & \multicolumn{10}{|c|}{ Porcentaje de empresas exportadoras DIRCE sobre exportadores } \\
\hline & 2010 & 2011 & 2012 & 2013 & 2014 & 2015 & 2016 & 2017 & 2018 & $\begin{array}{c}\text { Variación } \\
\text { 2018/2017 (pp) }\end{array}$ \\
\hline Extra UE (comercio declarado) .... & 64,4 & 66,8 & 65,2 & 61,6 & 63,3 & 64,3 & 63,7 & 57,2 & 46,0 & $-19,6$ \\
\hline UE (comercio declarado) ... & 88,8 & 90,4 & 90,8 & 89,6 & 89,1 & 87,3 & 86,7 & 87,1 & 87,2 & 0,2 \\
\hline Comercio declarado .... & 65,9 & 68,0 & 66,5 & 62,9 & 64,5 & 65,0 & 64,4 & 58,3 & 47,6 & $-18,4$ \\
\hline Comercio total ... & nd & nd & nd & nd & nd & 73,7 & 73,6 & 64,4 & 62,1 & $-3,6$ \\
\hline
\end{tabular}

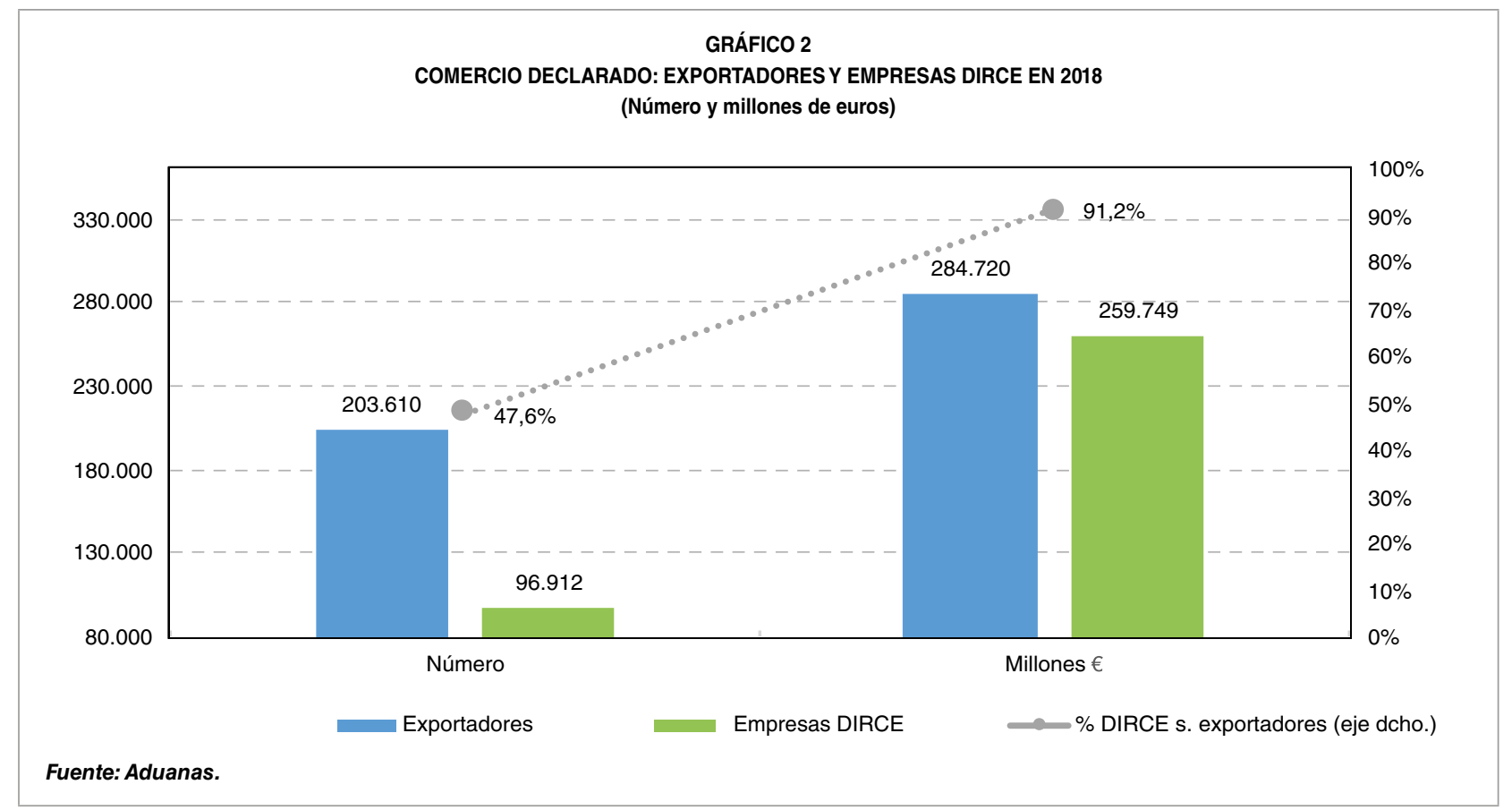


Subdirección General de Estudios y Evaluación de Instrumentos de Política Comercial

CUADRO 1B

VALOR DE LAS EXPORTACIONES DE EXPORTADORES Y EMPRESAS EXPORTADORAS DIRCE DE COMERCIO DECLARADO Y TOTAL

\begin{tabular}{|c|c|c|c|c|c|c|c|c|c|c|}
\hline \multirow[b]{2}{*}{ Concepto } & \multicolumn{10}{|c|}{ Valor exportado por exportadores (millones de euros) } \\
\hline & 2010 & 2011 & 2012 & 2013 & 2014 & 2015 & 2016 & 2017 & 2018 & $\begin{array}{l}\text { Variación } \\
\text { 2018/2017 (\%) }\end{array}$ \\
\hline Extra UE (comercio declarado) ..... & 60.489 & 72.871 & 83.115 & 88.093 & 87.735 & 88.075 & 86.093 & 94.758 & 97.179 & 2,6 \\
\hline UE (comercio declarado) ... & 126.291 & 142.359 & 143.000 & 147.722 & 152.847 & 161.719 & 170.300 & 181.385 & 187.540 & 3,4 \\
\hline Comercio declarado & 186.780 & 215.230 & 226.115 & 235.814 & 240.582 & 249.795 & 256.393 & 276.143 & 284.720 & 3,1 \\
\hline UE (comercio estimado) ${ }^{*} .$. & nd & 4.494 & 3.260 & 2.938 & 3.078 & 4.005 & 4.810 & 6.299 & 7.535 & 19,6 \\
\hline Comercio total ... & nd & 219.725 & 229.374 & 238.752 & 243.660 & 253.799 & 261.203 & 282.442 & 292.254 & 3,5 \\
\hline \multirow[b]{2}{*}{ Concepto } & \multicolumn{10}{|c|}{ Valor exportado por empresas DIRCE (millones de euros) } \\
\hline & 2010 & 2011 & 2012 & 2013 & 2014 & 2015 & 2016 & 2017 & 2018 & $\begin{array}{l}\text { Variación } \\
\text { 2018/2017 (\%) }\end{array}$ \\
\hline Extra UE (comercio declarado) ...... & 55.731 & 68.448 & 77.671 & 80.507 & 79.683 & 78.904 & 76.645 & 83.301 & 86.225 & 3,5 \\
\hline UE (comercio declarado) .................. & 116.524 & 130.320 & 131.816 & 133.751 & 139.138 & 150.028 & 158.557 & 167.768 & 173.524 & 3,4 \\
\hline Comercio declarado DIRCE .... & 172.255 & 198.768 & 209.488 & 214.258 & 218.821 & 228.932 & 235.203 & 251.069 & 259.749 & 3,5 \\
\hline Comercio total DIRCE & nd & nd & nd & nd & nd & 232.131 & 238.471 & 254.769 & 263.879 & 3,6 \\
\hline \multirow[b]{2}{*}{ Concepto } & \multicolumn{10}{|c|}{ Porcentaje de valor exportado por empresas exportadoras DIRCE sobre exportadores } \\
\hline & 2010 & 2011 & 2012 & 2013 & 2014 & 2015 & 2016 & 2017 & 2018 & $\begin{array}{c}\text { Variación } \\
\text { 2018/2017 (pp) }\end{array}$ \\
\hline Extra UE (comercio declarado) ...... & 92,1 & 93,9 & 93,5 & 91,4 & 90,8 & 89,6 & 89,0 & 87,9 & 88,7 & 0,9 \\
\hline UE (comercio declarado) .... & 92,3 & 91,5 & 92,2 & 90,5 & 91,0 & 92,8 & 93,1 & 92,5 & 92,5 & 0,0 \\
\hline Comercio declarado & 92,2 & 92,4 & 92,6 & 90,9 & 91,0 & 91,6 & 91,7 & 90,9 & 91,2 & 0,3 \\
\hline Comercio total ... & nd & nd & nd & nd & nd & 91,5 & 91,3 & 90,2 & 90,3 & 0,1 \\
\hline
\end{tabular}

regulares, ya que resultan de especial interés por sus implicaciones en la política de internacionalización. Así, en la Estrategia de Internacionalización de la Economía Española 2017-2027 se incorporó como reto y objetivo específico el aumento de la base de empresas que exportan regularmente. Para ello se introdujo, dentro de las medidas de apoyo de carácter general, la elaboración de programas que permitiesen a las empresas abordar la actividad exportadora de forma más regular. Entre los exportadores regulares también cabe distinguir entre operadores de comercio total y de comercio declarado $\mathrm{y}$, dentro de estos últimos, los que cruzan con el DIRCE.

Así, en 2018 hubo 51.740 exportadores regulares de comercio declarado que exportaron por valor de 272.077 millones. Si bien los exportadores regulares representaron únicamente el $25,4 \%$ de los exportadores de comercio declarado (203.610), abarcaron la práctica totalidad del valor exportado declarado $(95,6 \%$ del total o $97,0 \%$ si se restringe a las empresas DIRCE). La mayor parte de los exportadores regulares, 46.951 $(90,7 \%)$, cruzaron además con el DIRCE, y estas empresas fueron responsables del $92,6 \%$ de las exportaciones de exportadores regulares de comercio declarado (Cuadro 2). Se observa, por lo tanto, que las empresas DIRCE regulares determinan, en gran medida, el comportamiento del conjunto de exportadores regulares y, en buena medida, el conjunto de la exportación. Por ello, el estudio de sus características relevantes tiene particular relevancia para el diseño de las políticas de apoyo a la internacionalización. 
CUADRO 2

NÚMERO DE EXPORTADORES REGULARES Y VALOR DE SUS EXPORTACIONES (COMERCIO DECLARADO)

\begin{tabular}{|c|c|c|c|c|c|c|c|c|c|c|}
\hline \multirow[b]{2}{*}{ Concepto } & \multicolumn{10}{|c|}{ Número de exportadores } \\
\hline & 2010 & 2011 & 2012 & 2013 & 2014 & 2015 & 2016 & 2017 & 2018 & $\begin{array}{c}\text { Variación } \\
2018 / 2017(\%)\end{array}$ \\
\hline Exportadores regulares & 38.763 & 37.253 & 38.373 & 41.168 & 45.842 & 47.768 & 49.767 & 50.568 & 51.740 & 2,3 \\
\hline $\begin{array}{l}\text { Empresas exportadoras regulares } \\
\text { DIRCE }\end{array}$ & 35.428 & 35.983 & 37.008 & 38.419 & 41.887 & 43.699 & 45.487 & 46.037 & 46.951 & 2,0 \\
\hline \multirow[t]{3}{*}{$\begin{array}{l}\text { Empresas exportadoras regulares } \\
\text { DIRCE sobre exportadores regulares (\%) .... }\end{array}$} & 91,4 & 96,6 & 96,4 & 93,3 & 91,4 & 91,5 & 91,4 & 91,0 & 90,7 & $-0,3 \mathrm{pp}$ \\
\hline & \multicolumn{10}{|c|}{ Valor (millones de euros) } \\
\hline & 2010 & 2011 & 2012 & 2013 & 2014 & 2015 & 2016 & 2017 & 2018 & $\begin{array}{c}\text { Variación } \\
2018 / 2017(\%)\end{array}$ \\
\hline Exportadores regulares & 170.606 & 195.407 & 205.750 & 216.966 & 223.421 & 233.440 & 241.727 & 262.515 & 272.077 & 3,6 \\
\hline $\begin{array}{l}\text { Empresas exportadoras regulares } \\
\text { DIRCE }\end{array}$ & 160.291 & 185.813 & 194.555 & 201.207 & 207.005 & 218.290 & 225.661 & 242.019 & 251.871 & 4,1 \\
\hline $\begin{array}{l}\text { Empresas exportadoras regulares DIRCE } \\
\text { sobre exportadores regulares (\%) }\end{array}$ & 94,0 & 95,1 & 94,6 & 92,7 & 92,7 & 93,5 & 93,4 & 92,2 & 92,6 & $0,4 \mathrm{pp}$ \\
\hline
\end{tabular}

\section{Análisis de las empresas exportadoras DIRCE por estrato de asalariados}

El análisis de las empresas exportadoras según su tamaño revela la importancia de las pymes en la base exportadora española, aunque su contribución al valor de lo exportado es mucho menos significativa. Este predominio es menos acusado entre las empresas que exportan regularmente, ya que se observa una relación positiva entre regularidad y tamaño empresarial.

La clasificación de las empresas exportadoras DIRCE en función de su número de asalariados permite categorizar las empresas por tamaño empleando los criterios fijados por la Comisión Europea ${ }^{4}$.

\footnotetext{
4 Para las notaciones de tipología de empresa (microempresa, pequeña y mediana empresa o pyme) se utiliza la terminología de la Comisión Europea (recomendación 2003/361/CE), aunque tomando únicamente en consideración el número de asalariados. Por exclusión, las empresas de 250 o más asalariados se considerarán gran empresa (https://eur-lex.europa.eu/legal-content/ES/TXT/?uri=LEGISSUM \% 3An26026).
}

El número total de empresas exportadoras DIRCE creció en un 3,1\% en 2018. Esta evolución es resultado tanto del aumento del número de pymes exportadoras $(3,1 \%)$ como del número de grandes empresas que exportan $(3,0 \%)$. En lo que respecta al valor de las ventas exteriores, estas crecieron un 3,5\%, siendo en los estratos de mayor tamaño donde el valor exportado aumentó con mayor intensidad. Por el contrario, en el tramo de pequeña empresa, 10-49 asalariados, las ventas cayeron un $1,9 \%$.

Las pymes, definidas como aquellas empresas que disponen de menos de 250 asalariados, representaron en 2018 la inmensa mayoría de las empresas exportadoras DIRCE de comercio declarado en España, en concreto 94.475 , el $97,5 \%$ del total (96.912), y aportaron aproximadamente algo menos de la mitad del valor exportado $(49,4 \%)$. Dentro de estas destacaron en número las microempresas (hasta 9 asalariados), que supusieron el $64,4 \%$ del total, aunque aportaron solo el $11,8 \%$ del valor exportado. En el extremo opuesto, las grandes empresas (de 250 o más asalariados), a $\triangleright$ 
Subdirección General de Estudios y Evaluación de Instrumentos de Política Comercial

CUADRO 3

NÚMERO DE EMPRESAS EXPORTADORAS DIRCE POR ESTRATO DE ASALARIADOS Y VALOR DE SUS EXPORTACIONES (COMERCIO DECLARADO)

\begin{tabular}{|c|c|c|c|c|c|c|c|c|c|c|}
\hline \multirow[b]{2}{*}{ Estrato de asalariados } & \multicolumn{5}{|c|}{ Número de empresas exportadoras DIRCE } & \multicolumn{5}{|c|}{ Valor (millones de euros) } \\
\hline & 2010 & 2015 & 2017 & 2018 & $\begin{array}{l}\text { Variación } \\
2018 / 2017(\%)\end{array}$ & 2010 & 2015 & 2017 & 2018 & $\begin{array}{l}\text { Variación } \\
\text { 2018/2017 (\%) }\end{array}$ \\
\hline 0 - 9 microempresa & 42.857 & 61.939 & 59.851 & 62.409 & 4,3 & 20.510 & 25.506 & 29.820 & 30.713 & 3,0 \\
\hline $10-49 \ldots$ & 20.423 & 23.864 & 23.699 & 23.789 & 0,4 & 25.467 & 32.447 & 35.097 & 34.441 & $-1,9$ \\
\hline $50-199 \ldots$ & 6.322 & 7.121 & 7.470 & 7.620 & 2,0 & 33.083 & 45.489 & 50.881 & 52.429 & 3,0 \\
\hline $200-249 \ldots \ldots$ & 530 & 593 & 625 & 657 & 5,1 & 6.678 & 9.289 & 10.090 & 10.718 & 6,2 \\
\hline $0-249$ pyme & 70.132 & 93.517 & 91.645 & 94.475 & 3,1 & 85.739 & 112.732 & 125.888 & 128.301 & 1,9 \\
\hline $250-499$ & 1.021 & 1.147 & 1.253 & 1.294 & 3,3 & 20.357 & 20.992 & 26.292 & 27.807 & 5,8 \\
\hline$>=500 \ldots$ & 894 & 1.039 & 1.112 & 1.143 & 2,8 & 66.159 & 95.208 & 98.889 & 103.642 & 4,8 \\
\hline$>=250$ gran empresa & 1.915 & 2.186 & 2.365 & 2.437 & 3,0 & 86.516 & 116.200 & 125.181 & 131.449 & 5,0 \\
\hline Total $\ldots$. & 72.047 & 95.703 & 94.010 & 96.912 & 3,1 & 172.255 & 228.932 & 251.069 & 259.749 & 3,5 \\
\hline \multirow{2}{*}{ Estrato de asalariados } & \multicolumn{5}{|c|}{$\begin{array}{c}\text { Porcentaje por estrato sobre el total de empresas } \\
\text { exportadoras DIRCE }\end{array}$} & \multicolumn{5}{|c|}{$\begin{array}{l}\text { Porcentaje por estrato sobre el valor } \\
\text { (millones de euros) }\end{array}$} \\
\hline & 2010 & 2015 & 2017 & 2018 & $\begin{array}{l}\text { Variación } \\
\text { 2018/2017 (pp) }\end{array}$ & 2010 & 2015 & 2017 & 2018 & $\begin{array}{l}\text { Variación } \\
\text { 2018/2017 (pp) }\end{array}$ \\
\hline 0 - 9 microempresa & 59,5 & 64,7 & 63,7 & 64,4 & 0,7 & 11,9 & 11,1 & 11,9 & 11,8 & $-0,1$ \\
\hline $10-49$ & 28,3 & 24,9 & 25,2 & 24,5 & $-0,7$ & 14,8 & 14,2 & 14,0 & 13,3 & $-0,7$ \\
\hline $50-199$ & 8,8 & 7,4 & 7,9 & 7,9 & $-0,1$ & 19,2 & 19,9 & 20,3 & 20,2 & $-0,1$ \\
\hline $200-249$ & 0,7 & 0,6 & 0,7 & 0,7 & 0,0 & 3,9 & 4,1 & 4,0 & 4,1 & 0,1 \\
\hline 0 - 249 pyme & 97,3 & 97,7 & 97,5 & 97,5 & 0,0 & 49,8 & 49,2 & 50,1 & 49,4 & $-0,7$ \\
\hline $250-499$ & 1,4 & 1,2 & 1,3 & 1,3 & 0,0 & 11,8 & 9,2 & 10,5 & 10,7 & 0,2 \\
\hline$>=500 \ldots \ldots$ & 1,2 & 1,1 & 1,2 & 1,2 & 0,0 & 38,4 & 41,6 & 39,4 & 39,9 & 0,5 \\
\hline$>=250$ gran empresa & 2,7 & 2,3 & 2,5 & 2,5 & 0,0 & 50,2 & 50,8 & 49,9 & 50,6 & 0,7 \\
\hline Total & 100,0 & 100,0 & 100,0 & 100,0 & - & 100,0 & 100,0 & 100,0 & 100,0 & - \\
\hline
\end{tabular}

pesar de representar únicamente el 2,5\% del total, fueron responsables de algo más de la mitad del valor exportado: 50,6\% (Cuadro 3).

Por su parte, el número de empresas DIRCE que exportan de forma regular ha continuado aumentando en 2018, hasta alcanzar las 46.951 (Cuadro 4A). Se observa, además, que la presencia de grandes empresas es mayor, tanto en el valor exportado $(51,8 \%)$ como sobre todo en el número de empresas (4,2\%). De forma complementaria, las pymes representaron un porcentaje menor en las regulares, en especial, por la menor regularidad mostrada por las microempresas, que en el año 2018 supusieron el $64,4 \%$ del total de empresas DIRCE y tan solo el $47,8 \%$ de las regulares DIRCE.

La propensión a la regularidad tiende a aumentar con el tamaño de la empresa. Además, las empresas regulares son responsables de la práctica totalidad de las exportaciones realizadas por empresas DIRCE. La contribución de las empresas regulares al valor de la exportación aumenta en los estratos de mayor tamaño. Así, a partir de la información mostrada en los dos cuadros anteriores se puede calcular la proporción de empresas exportadoras DIRCE que exportan regularmente y el peso de sus $D$ 
CUADRO 4A

NÚMERO DE EMPRESAS EXPORTADORAS REGULARES DIRCE POR ESTRATO DE ASALARIADOSY VALOR DE SUS EXPORTACIONES (COMERCIO DECLARADO)

\begin{tabular}{|c|c|c|c|c|c|c|c|c|c|c|}
\hline \multirow[b]{2}{*}{ Estrato de asalariados } & \multicolumn{5}{|c|}{ Número de empresas regulares DIRCE } & \multicolumn{5}{|c|}{ Valor de las exportaciones (millones de euros) } \\
\hline & 2010 & 2015 & 2017 & 2018 & $\begin{array}{c}\text { Variación } \\
2018 / 2017(\%)\end{array}$ & 2010 & 2015 & 2017 & 2018 & $\begin{array}{c}\text { Variación } \\
2018 / 2017(\%)\end{array}$ \\
\hline 0 - 9 microempresa & 15.624 & 20.935 & 21.938 & 22.459 & 2,4 & 15.354 & 21.157 & 26.445 & 27.352 & 3,4 \\
\hline $10-49$ & 13.116 & 15.125 & 15.855 & 16.009 & 1,0 & 22.858 & 29.802 & 33.194 & 32.548 & $-1,9$ \\
\hline $50-199 \ldots$ & 4.771 & 5.401 & 5.834 & 5.966 & 2,3 & 31.509 & 42.896 & 49.160 & 50.977 & 3,7 \\
\hline $200-249$ & 424 & 476 & 508 & 541 & 6,5 & 6.548 & 9.040 & 10.048 & 10.548 & 5,0 \\
\hline 0 - 249 pyme & 33.935 & 41.937 & 44.135 & 44.975 & 1,9 & 76.269 & 102.895 & 118.848 & 121.425 & 2,2 \\
\hline $250-499$ & 809 & 927 & 1.005 & 1.040 & 3,5 & 19.892 & 20.566 & 24.702 & 27.157 & 9,9 \\
\hline$>=500$ & 684 & 835 & 897 & 936 & 4,3 & 64.130 & 94.829 & 98.470 & 103.288 & 4,9 \\
\hline$>=250$ gran empresa & 1.493 & 1.762 & 1.902 & 1.976 & 3,9 & 84.022 & 115.395 & 123.171 & 130.445 & 5,9 \\
\hline Total & 35.428 & 43.699 & 46.037 & 46.951 & 2,0 & 160.291 & 218.290 & 242.019 & 251.871 & 4,1 \\
\hline \multirow[t]{2}{*}{ Estrato de asalariados } & \multicolumn{5}{|c|}{$\begin{array}{l}\text { Porcentaje por estrato sobre el total de empresas } \\
\text { exportadoras regulares DIRCE }\end{array}$} & \multicolumn{5}{|c|}{$\begin{array}{l}\text { Porcentaje por estrato sobre el valor total de las } \\
\text { exportaciones de empresas exportadoras regulares } \\
\text { DIRCE }\end{array}$} \\
\hline & 2010 & 2015 & 2017 & 2018 & $\begin{array}{c}\text { Variación } \\
2018 / 2017(p p)\end{array}$ & 2010 & 2015 & 2017 & 2018 & $\begin{array}{l}\text { Variación } \\
2018 / 2017(p p)\end{array}$ \\
\hline 0 - 9 microempresa & 44,1 & 47,9 & 47,7 & 47,8 & 0,2 & 9,6 & 9,7 & 10,9 & 10,9 & $-0,1$ \\
\hline $10-49$ & 37,0 & 34,6 & 34,4 & 34,1 & $-0,3$ & 14,3 & 13,7 & 13,7 & 12,9 & $-0,8$ \\
\hline $50-199 \ldots$ & 13,5 & 12,4 & 12,7 & 12,7 & 0,0 & 19,7 & 19,7 & 20,3 & 20,2 & $-0,1$ \\
\hline $200-249 \ldots$. & 1,2 & 1,1 & 1,1 & 1,2 & 0,0 & 4,1 & 4,1 & 4,2 & 4,2 & 0,0 \\
\hline 0 - 249 pyme & 95,8 & 96,0 & 95,9 & 95,8 & $-0,1$ & 47,6 & 47,1 & 49,1 & 48,2 & $-0,9$ \\
\hline $250-499 \ldots$ & 2,3 & 2,1 & 2,2 & 2,2 & 0,0 & 12,4 & 9,4 & 10,2 & 10,8 & 0,6 \\
\hline$>=500$ & 1,9 & 1,9 & 1,9 & 2,0 & 0,0 & 40,0 & 43,4 & 40,7 & 41,0 & 0,3 \\
\hline$>=250$ gran empresa & 4,2 & 4,0 & 4,1 & 4,2 & 0,1 & 52,4 & 52,9 & 50,9 & 51,8 & 0,9 \\
\hline Total & 100,0 & 100,0 & 100,0 & 100,0 & - & 100,0 & 100,0 & 100,0 & 100,0 & - \\
\hline
\end{tabular}

exportaciones sobre el valor del comercio declarado (Cuadro 4B). Por estrato de asalariados se observa que la propensión a la regularidad aumenta con el tamaño hasta estabilizarse en torno al $80 \%$ en las medianas y grandes empresas. En cuanto al valor exportado, en media, el 97,0\% es realizado por las empresas regulares; en la banda baja se encuentran las microempresas regulares, que contribuyen con el $89,1 \%$ del total del valor exportado por las empresas de ese estrato de tamaño; y en la banda alta, las empresas de 500 o más asalariados regulares, que contribuyen con el $99,7 \%$ de las exportaciones realizadas por empresas de 500 o más asalariados.

\section{Análisis de la empresa exportadora DIRCE por actividad principal}

La base exportadora española está constituida principalmente por empresas comerciales y manufactureras. Resulta especialmente significativa la contribución de las empresas manufactureras al valor exportado. Este rasgo cobra mayor intensidad cuando el análisis se centra en las empresas que exportan de forma regular. Se constata, además, que las empresas manufactureras muestran una mayor propensión a la regularidad exportadora y que el predominio de la pyme exportadora es más acusado en el comercio que en la industria. $D$ 
CUADRO 4B

PORCENTAJE DE REGULARES DE LAS EMPRESAS EXPORTADORAS DIRCE (COMERCIO DECLARADO)

\begin{tabular}{|c|c|c|c|c|c|c|c|c|c|c|}
\hline \multirow[b]{2}{*}{ Estrato de asalariados } & \multicolumn{5}{|c|}{ En número de empresas DIRCE (\%) } & \multicolumn{5}{|c|}{ En valor de las exportaciones (\%) } \\
\hline & 2010 & 2015 & 2017 & 2018 & $\begin{array}{c}\text { Variación } \\
\text { 2018/2017 (pp) }\end{array}$ & 2010 & 2015 & 2017 & 2018 & $\begin{array}{c}\text { Variación } \\
\text { 2018/2017 (pp) }\end{array}$ \\
\hline 0 - 9 microempresa & 36,5 & 33,8 & 36,7 & 36,0 & $-0,7$ & 74,9 & 82,9 & 88,7 & 89,1 & 0,4 \\
\hline $10-49 \ldots$ & 64,2 & 63,4 & 66,9 & 67,3 & 0,4 & 89,8 & 91,8 & 94,6 & 94,5 & $-0,1$ \\
\hline $50-199 \ldots$ & 75,5 & 75,8 & 78,1 & 78,3 & 0,2 & 95,2 & 94,3 & 96,6 & 97,2 & 0,6 \\
\hline $200-249$ & 80,0 & 80,3 & 81,3 & 82,3 & 1,1 & 98,1 & 97,3 & 99,6 & 98,4 & $-1,2$ \\
\hline 0 - 249 pyme & 48,4 & 44,8 & 48,2 & 47,6 & $-0,6$ & 89,0 & 91,3 & 94,4 & 94,6 & 0,2 \\
\hline $250-499$ & 79,2 & 80,8 & 80,2 & 80,4 & 0,2 & 97,7 & 98,0 & 93,9 & 97,7 & 3,7 \\
\hline$>=500$ & 76,5 & 80,4 & 80,7 & 81,9 & 1,2 & 96,9 & 99,6 & 99,6 & 99,7 & 0,1 \\
\hline$>=250$ gran empresa & 78,0 & 80,6 & 80,4 & 81,1 & 0,7 & 97,1 & 99,3 & 98,4 & 99,2 & 0,8 \\
\hline Total & 49,2 & 45,7 & 49,0 & 48,4 & $-0,5$ & 93,1 & 95,4 & 96,4 & 97,0 & 0,6 \\
\hline
\end{tabular}

En este sector, además, las empresas contabilizan valores medios de exportación más elevados.

Atendiendo a la actividad principal de la empresa, en 2018 el mayor número de empresas exportadoras correspondió al comercio (sección $\mathrm{G}$ de la CNAE 2009), con el 43,0\% del total, debido especialmente a la división de comercio al por mayor e intermediarios del comercio, que por sí sola representó el 30,6\% del total. En segundo lugar, figura la industria manufacturera (sección C), con el 26,6\% de las empresas exportadoras DIRCE (Cuadro 5).

Las empresas manufactureras junto con las comerciales explican la práctica totalidad del valor de las exportaciones. Así, en 2018, el $95,6 \%$ del valor de las exportaciones es atribuible a empresas cuya actividad principal estaba comprendida en estas dos secciones ( $\mathrm{C}$ y $G)$, dejando un valor residual para el resto de actividades. En el valor de las exportaciones, la importancia de las aportaciones de la industria manufacturera y el comercio se invierte respecto a su peso en el número de empresas exportadoras. Así, las empresas de la industria manufacturera aglutinaron el $65,2 \%$ de las exportaciones totales, frente al $30,4 \%$ del comercio, con un $24,7 \%$ del total atribuible a la división del comercio al por mayor. Si analizamos las exportaciones medias por empresa, las de la industria manufactura son claramente superiores a las del comercio al por mayor: 6,6 millones frente a 2,2 millones. Dentro de la industria manufacturera destacan las de la división de coquerías y refino de petróleo con más de 1.100 millones por empresa y, a gran distancia, las correspondientes a la fabricación de vehículos de motor con cerca de 69 millones.

Estos rasgos se intensifican cuando el análisis se centra en las empresas regulares. Así, entre las empresas exportadoras regulares DIRCE (Cuadro 6) dominan en número y con mayor peso las empresas del comercio $(45,6 \%)$, en especial las de la división de comercio al por mayor (37,6\%), y las correspondientes a la industria manufacturera $(37,8 \%)$. En lo que respecta al valor exportado, la industria manufacturera representa prácticamente dos tercios de las exportaciones $(66,1 \%)$, por un $29,9 \%$ de las empresas del comercio, $y$, dentro de estas, el $24,2 \%$ corresponden al comercio al por mayor. 
CUADRO 5

NÚMERO DE EMPRESAS EXPORTADORAS DIRCE Y VALOR EXPORTADO (COMERCIO DECLARADO) POR ACTIVIDAD PRINCIPAL (CNAE 2009)

\begin{tabular}{|c|c|c|c|c|c|c|c|c|c|c|c|}
\hline \multirow{3}{*}{\multicolumn{2}{|c|}{ CNAE-2009 }} & \multicolumn{4}{|c|}{$\begin{array}{c}\text { Núm. de empresas exportadoras } \\
\text { DIRCE }\end{array}$} & \multicolumn{6}{|c|}{ Valor exportado } \\
\hline & & \multicolumn{2}{|c|}{ Núm. empresas } & \multicolumn{2}{|c|}{$\begin{array}{l}\text { Peso s. total } \\
\text { (\%) }\end{array}$} & \multicolumn{2}{|c|}{ Millones de euros } & \multicolumn{2}{|c|}{$\begin{array}{l}\text { Peso s. total } \\
(\%)\end{array}$} & \multicolumn{2}{|c|}{$\begin{array}{l}\text { Export. media } \\
\text { (Millones de euros) }\end{array}$} \\
\hline & & 2017 & 2018 & 2017 & 2018 & 2017 & 2018 & 2017 & 2018 & 2017 & 2018 \\
\hline A & Agricultura, ganadería, silvicultura y pesca ...... & 2.017 & 1.986 & 2,1 & 2,0 & 2.500 & 2.591 & 1,0 & 1,0 & 1,2 & 1,3 \\
\hline B & Industrias extractivas ... & 221 & 230 & 0,2 & 0,2 & 820 & 848 & 0,3 & 0,3 & 3,7 & 3,7 \\
\hline C & Industria manufacturera . & 25.795 & 25.806 & 27,4 & 26,6 & 164.180 & 169.395 & 65,4 & 65,2 & 6,4 & 6,6 \\
\hline 10 & Industria de la alimentación . & 3.232 & 3.255 & 3,4 & 3,4 & 18.575 & 18.863 & 7,4 & 7,3 & 5,7 & 5,8 \\
\hline 11 & Fabricación de bebidas ............ & 2.000 & 1.984 & 2,1 & 2,0 & 2.546 & 2.689 & 1,0 & 1,0 & 1,3 & 1,4 \\
\hline 12 & Industria del tabaco ............ & 18 & 18 & 0,0 & 0,0 & 118 & 116 & 0,0 & 0,0 & 6,6 & 6,4 \\
\hline 13 & 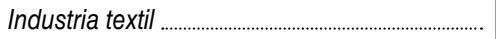 & 1.074 & 1.065 & 1,1 & 1,1 & 2.180 & 2.195 & 0,9 & 0,8 & 2,0 & 2,1 \\
\hline 14 & Confección de prendas de vestir .......... & 1.062 & 1.069 & 1,1 & 1,1 & 1.263 & 1.214 & 0,5 & 0,5 & 1,2 & 1,1 \\
\hline 15 & Industria del cuero y del calzado ................................ & 973 & 950 & 1,0 & 1,0 & 1.689 & 1.728 & 0,7 & 0,7 & 1,7 & 1,8 \\
\hline 16 & Ind. de la mad. y del corcho, exc. muebles .... & 729 & 713 & 0,8 & 0,7 & 1.329 & 1.386 & 0,5 & 0,5 & 1,8 & 1,9 \\
\hline 17 & Industria del papel ... & 488 & 474 & 0,5 & 0,5 & 3.282 & 3.414 & 1,3 & 1,3 & 6,7 & 7,2 \\
\hline 18 & Artes gráf. y reprod. de soportes grabados .... & 922 & 972 & 1,0 & 1,0 & 608 & 617 & 0,2 & 0,2 & 0,7 & 0,6 \\
\hline 19 & Coquerías y refino de petróleo & 10 & 10 & 0,0 & 0,0 & 8.904 & 11.035 & 3,5 & 4,2 & 890,4 & $1.103,5$ \\
\hline 20 & Industria química & 1.417 & 1.460 & 1,5 & 1,5 & 14.745 & 15.498 & 5,9 & 6,0 & 10,4 & 10,6 \\
\hline 21 & Fabricación de productos farmacéuticos ......... & 219 & 223 & 0,2 & 0,2 & 5.523 & 5.561 & 2,2 & 2,1 & 25,2 & 24,9 \\
\hline 22 & Fab. de productos de caucho y plásticos ........ & 1.422 & 1.454 & 1,5 & 1,5 & 6.577 & 6.817 & 2,6 & 2,6 & 4,6 & 4,7 \\
\hline 23 & Fab. de otros prod. minerales no metálicos .... & 1.222 & 1.167 & 1,3 & 1,2 & 5.110 & 5.210 & 2,0 & 2,0 & 4,2 & 4,5 \\
\hline 24 & Metalurgia; fab. productos de hierro, acero ... & 440 & 440 & 0,5 & 0,5 & 13.416 & 14.348 & 5,3 & 5,5 & 30,5 & 32,6 \\
\hline 25 & Fab. prod. metálicos, exc. maq. y equipo ........ & 2.970 & 2.951 & 3,2 & 3,0 & 8.874 & 9.408 & 3,5 & 3,6 & 3,0 & 3,2 \\
\hline 26 & Fab. prod. infor., electrónicos y ópticos ............. & 662 & 673 & 0,7 & 0,7 & 1.607 & 1.612 & 0,6 & 0,6 & 2,4 & 2,4 \\
\hline 27 & Fabricación de material y equipo eléctrico ...... & 672 & 671 & 0,7 & 0,7 & 7.994 & 8.153 & 3,2 & 3,1 & 11,9 & 12,2 \\
\hline 28 & Fab. de maquinaria y equipo n.c.o.p. .................. & 2.242 & 2.260 & 2,4 & 2,3 & 9.205 & 9.656 & 3,7 & 3,7 & 4,1 & 4,3 \\
\hline 29 & Fab. de vehículos de motor, remolques ............. & 587 & 580 & 0,6 & 0,6 & 39.601 & 39.865 & 15,8 & 15,3 & 67,5 & 68,7 \\
\hline 30 & Fabricación de otro material de transporte ...... & 247 & 252 & 0,3 & 0,3 & 8.485 & 7.494 & 3,4 & 2,9 & 34,4 & 29,7 \\
\hline 31 & 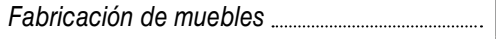 & 1.005 & 943 & 1,1 & 1,0 & 1.002 & 947 & 0,4 & 0,4 & 1,0 & 1,0 \\
\hline 32 & Otras industrias manufactureras ............................. & 1.124 & 1.121 & 1,2 & 1,2 & 1.218 & 1.180 & 0,5 & 0,5 & 1,1 & 1,1 \\
\hline 33 & Rep. e instalación de maquinaria y equipo ..... & 1.058 & 1.101 & 1,1 & 1,1 & 326 & 387 & 0,1 & 0,1 & 0,3 & 0,4 \\
\hline $\mathrm{D}$ & Suministro de energía eléctrica, gas ..................... & 78 & 84 & 0,1 & 0,1 & 505 & 532 & 0,2 & 0,2 & 6,5 & 6,3 \\
\hline$E$ & Suministro de agua, act. saneamiento .................. & 322 & 330 & 0,3 & 0,3 & 505 & 522 & 0,2 & 0,2 & 1,6 & 1,6 \\
\hline $\mathrm{F}$ & Construcción & 2.895 & 3.019 & 3,1 & 3,1 & 1.058 & 1.041 & 0,4 & 0,4 & 0,4 & 0,3 \\
\hline $\mathbf{G}$ & Com. por mayor y menor; rep. vehículos .... & 41.155 & 41.656 & 43,8 & 43,0 & 75.781 & 79.009 & 30,2 & 30,4 & 1,8 & 1,9 \\
\hline 45 & Venta y reparación de vehículos de motor ....... & 3.093 & 3.139 & 3,3 & 3,2 & 7.787 & 8.591 & 3,1 & 3,3 & 2,5 & 2,7 \\
\hline 46 & Com. al por mayor e inter. del com. ..................... & 29.630 & 29.701 & 31,5 & 30,6 & 61.650 & 64.062 & 24,6 & 24,7 & 2,1 & 2,2 \\
\hline 47 & Comercio al por menor & 8.432 & 8.816 & 9,0 & 9,1 & 6.343 & 6.356 & 2,5 & 2,4 & 0,8 & 0,7 \\
\hline $\mathrm{H}$ & Transporte y almacenamiento & 3.245 & 3.997 & 3,5 & 4,1 & 1.905 & 1.608 & 0,8 & 0,6 & 0,6 & 0,4 \\
\hline I & Hostelería & 1.112 & 1.415 & 1,2 & 1,5 & 131 & 143 & 0,1 & 0,1 & 0,1 & 0,1 \\
\hline $\mathrm{J}$ & Información y comunicaciones .................................. & 2.294 & 2.294 & 2,4 & 2,4 & 796 & 734 & 0,3 & 0,3 & 0,3 & 0,3 \\
\hline $\mathrm{K}$ & Actividades financieras y de seguros ..................... & 384 & 480 & 0,4 & 0,5 & 342 & 214 & 0,1 & 0,1 & 0,9 & 0,4 \\
\hline$L$ & Actividades inmobiliarias & 578 & 626 & 0,6 & 0,6 & 47 & 90 & 0,0 & 0,0 & 0,1 & 0,1 \\
\hline M & Act. profesionales, científicas y técnicas ............. & 5.685 & 5.920 & 6,0 & 6,1 & 1.406 & 1.255 & 0,6 & 0,5 & 0,2 & 0,2 \\
\hline $\mathrm{N}$ & Act. administrativas y servicios auxiliares ......... & 2.821 & 3.163 & 3,0 & 3,3 & 941 & 1.662 & 0,4 & 0,6 & 0,3 & 0,5 \\
\hline 0 & Admón. pública y defensa; SS obligatoria ......... & 133 & 99 & 0,1 & 0,1 & 2 & 5 & 0,0 & 0,0 & 0,0 & 0,0 \\
\hline$P$ & 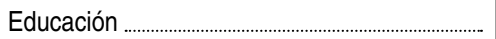 & 817 & 834 & 0,9 & 0,9 & 12 & 8 & 0,0 & 0,0 & 0,0 & 0,0 \\
\hline Q & Act. sanitarias y de servicios sociales .................... & 1.326 & 1.424 & 1,4 & 1,5 & 25 & 8 & 0,0 & 0,0 & 0,0 & 0,0 \\
\hline $\mathrm{R}$ & Act. artísticas, recreativas y entretenimiento ... & 1.349 & 1.566 & 1,4 & 1,6 & 38 & 36 & 0,0 & 0,0 & 0,0 & 0,0 \\
\hline S & Otros servicios & 1.270 & 1.425 & 1,4 & 1,5 & 54 & 40 & 0,0 & 0,0 & 0,0 & 0,0 \\
\hline $\mathrm{T}$ & Actividades de los hogares & 457 & 515 & 0,5 & 0,5 & 6 & 6 & 0,0 & 0,0 & 0,0 & 0,0 \\
\hline \multirow[t]{2}{*}{$U$} & Act. de organizaciones extraterritoriales .............. & 56 & 43 & 0,1 & 0,0 & 14 & 3 & 0,0 & 0,0 & 0,3 & 0,1 \\
\hline & Total . & 94.010 & 96.912 & 100,0 & 100,0 & 251.069 & 259.749 & 100,0 & 100,0 & 2,7 & 2,7 \\
\hline
\end{tabular}


Las empresas manufactureras muestran una mayor propensión a la regularidad exportadora que las correspondientes a otras ramas de actividad. Así, el 68,9\% de las empresas exportadoras DIRCE de la industria manufacturera eran exportadores regulares, muy por encima de la media para el conjunto de actividades $(48,4 \%)$. En la sección comercio, el comportamiento fue muy dispar según se trate de empresas exportadoras del comercio al por mayor, entre las que el 59,4\% exportaron regularmente, o del comercio al por menor, entre las que solo el $27,9 \%$ lo hicieron.

En relación con el valor exportado, las empresas regulares DIRCE aglutinaron en su conjunto el $97,0 \%$ del valor exportado por las empresas DIRCE. Este porcentaje fue incluso superior para las empresas de la industria manufacturera, que ascendió hasta el 98,3\%. Para el conjunto del comercio fue inferior, $95,2 \%$, y, dentro de este, también para el comercio al por mayor, un 95,1\%.

Al realizar el cruce de tamaño y sector, se aprecian claras diferencias entre las empresas cuya actividad principal corresponde a la industria en sentido amplio (secciones B, C, D y E de la CNAE 2009) o al comercio (sección G) (Cuadro 7). En la distribución de las empresas por estratos de asalariados, se observa que en ambos casos dominaron las pymes, con el $96,7 \%$ en la industria y el $98,8 \%$ en el comercio. No obstante, dentro de las pymes las diferencias son sustanciales, ya que en el comercio las microempresas destacaron con el $74,9 \%$ del total de empresas $(40,6 \%$ en la industria), mientras que en la industria predominaron las pequeñas y medianas con el $56,1 \%$ del total (23,9\% en el comercio). En el extremo opuesto, el peso de la gran empresa en la industria $(3,3 \%)$ prácticamente triplicó al del comercio $(1,2 \%)$.
Estas diferencias son más marcadas cuando se analiza la contribución al valor de las exportaciones. Así, la mayor parte del valor exportado en la industria $(61,3 \%)$ lo realizaron las grandes empresas, que representaron únicamente el 3,3\% de las empresas exportadoras de la industria, mientras que en el comercio fueron las pymes las que aglutinaron el 70,6\% de las exportaciones, destacando el papel de las microempresas $(31,0 \%$ en valor, frente al $2,3 \%$ del valor en la industria). Las grandes empresas de la industria, a pesar de representar menos de un $1 \%$ del total de las empresas exportadoras DIRCE de comercio declarado, fueron responsables de más del $40 \%$ de las exportaciones totales.

Al analizar el valor medio exportado, se observa que las empresas industriales, en promedio, exportaron más que las del comercio, 6,5 millones frente a 1,9 millones. Este hecho también se repitió en todos los tramos, excepto en las microempresas exportadoras DIRCE, donde las del comercio exportaron en media casi el doble que las de la industria, 0,8 millones frente a 0,4 millones, y en las pequeñas empresas (10-49 asalariados), aunque con una diferencia menor. A medida que va aumentando el tamaño, la diferencia en favor de la industria va incrementándose. Así, en la gran empresa, las empresas exportadoras industriales exportaron en media 2,6 veces lo exportado por las pertenecientes al comercio.

En síntesis, en cuanto al número de empresas exportadoras, dominan las comerciales, seguidas a distancia de las de la industria manufacturera, mientras que este orden se invierte cuando lo que se analiza es el volumen exportado. Las empresas de la industria manufacturera mostraron una regularidad muy superior a la del conjunto de empresas y también $\triangleright$ 
CUADRO 6

NÚMERO DE EMPRESAS EXPORTADORAS REGULARES, VALOR DE SUS EXPORTACIONESY SOBRE TOTAL (COMERCIO DECLARADO) POR ACTIVIDAD PRINCIPAL (CNAE-2009) EN 2018

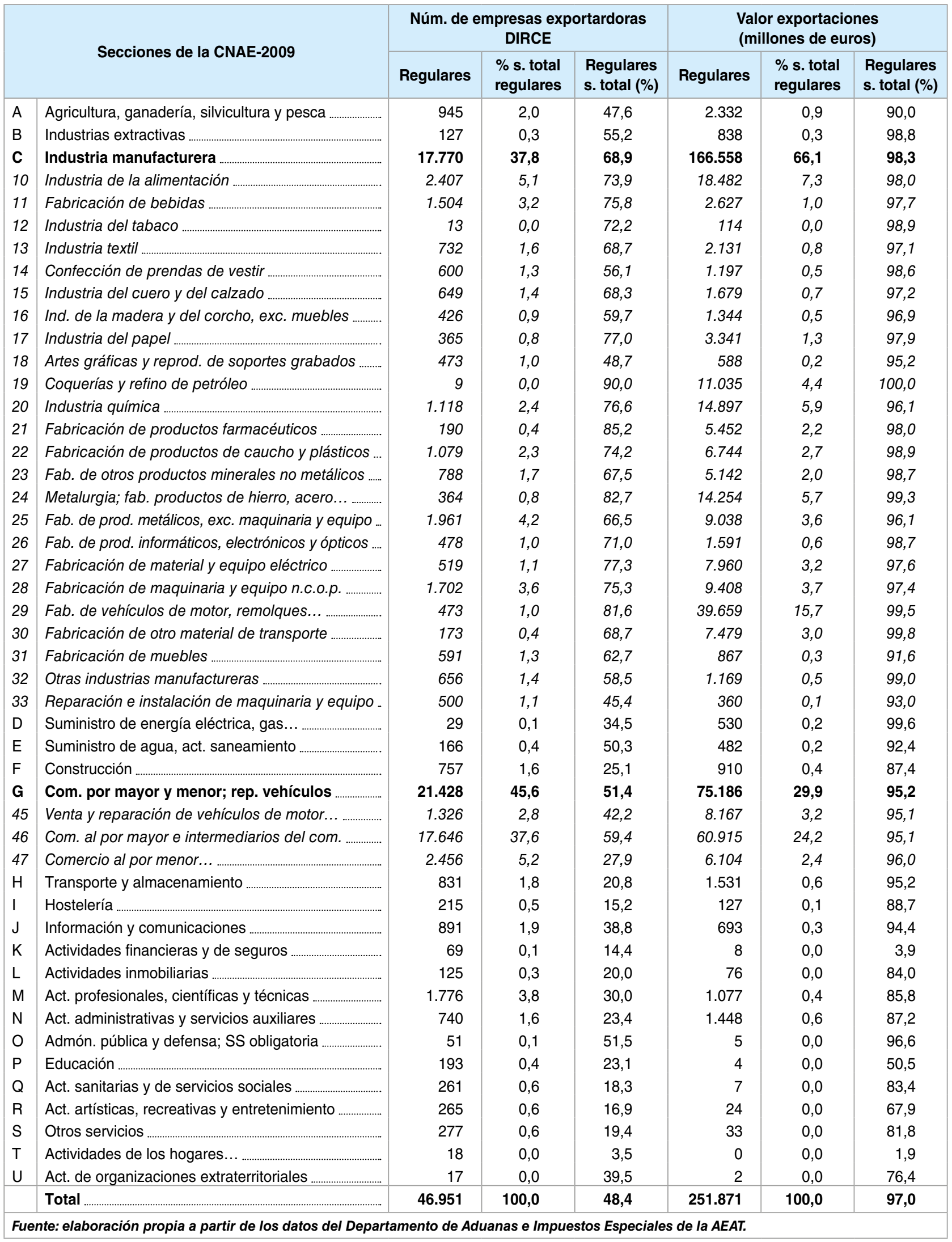


Subdirección General de Estudios y Evaluación de Instrumentos de Política Comercial

CUADRO 7

NÚMERO DE EMPRESAS EXPORTADORAS DIRCE Y VALOR EXPORTADO (COMERCIO DECLARADO) POR ESTRATO DE ASALARIADOS Y ACTIVIDAD ECONÓMICA EN 2018

\begin{tabular}{|c|c|c|c|c|c|c|c|c|}
\hline \multirow[b]{2}{*}{ Estrato de asalariados } & \multicolumn{4}{|c|}{ Número de Empresas } & \multicolumn{4}{|c|}{ Valor exportado (millones de euros) } \\
\hline & $\begin{array}{l}\text { Industria } \\
\text { (BCDE) }\end{array}$ & $\begin{array}{l}\text { Comercio } \\
\text { (G) }\end{array}$ & Resto & Total & $\begin{array}{l}\text { Industria } \\
\text { (BCDE) }\end{array}$ & $\begin{array}{l}\text { Comercio } \\
\text { (G) }\end{array}$ & Resto & Total \\
\hline 0-9 microempresa & 10.733 & 31.186 & 20.490 & 62.409 & 3.944 & 24.496 & 2.273 & 30.713 \\
\hline $10-49$ & 10.918 & 7.781 & 5.090 & 23.789 & 17.296 & 15.271 & 1.874 & 34.441 \\
\hline $50-199$ & 3.631 & 2.038 & 1.951 & 7.620 & 36.357 & 14.123 & 1.949 & 52.429 \\
\hline $200-249 \ldots$ & 300 & 146 & 211 & 657 & 8.656 & 1.865 & 197 & 10.718 \\
\hline 0-249 pyme & 25.582 & 41.151 & 27.742 & 94.475 & 66.253 & 55.754 & 6.294 & 128.301 \\
\hline $250-499 \ldots$ & 556 & 278 & 460 & 1.294 & 21.908 & 5.257 & 641 & 27.807 \\
\hline 500 o más & 312 & 227 & 604 & 1.143 & 83.136 & 17.998 & 2.508 & 103.642 \\
\hline$>=250$ gran empresa $\ldots$ & 868 & 505 & 1.064 & 2.437 & 105.044 & 23.255 & 3.149 & 131.449 \\
\hline Total declarado DIRCE & 26.450 & 41.656 & 28.806 & 96.912 & 171.297 & 79.009 & 9.443 & 259.749 \\
\hline \multirow{2}{*}{ Estrato de asalariados } & \multicolumn{4}{|c|}{$\begin{array}{l}\text { Porcentaje de número de empresas sobre total } \\
\text { de la columna }\end{array}$} & \multicolumn{4}{|c|}{$\begin{array}{c}\text { Porcentaje de valor exportado sobre total } \\
\text { de la columna }\end{array}$} \\
\hline & $\begin{array}{l}\text { Industria } \\
\text { (BCDE) }\end{array}$ & $\begin{array}{l}\text { Comercio } \\
\text { (G) }\end{array}$ & Resto & Total & $\begin{array}{l}\text { Industria } \\
\text { (BCDE) }\end{array}$ & $\begin{array}{l}\text { Comercio } \\
\text { (G) }\end{array}$ & Resto & Total \\
\hline 0-9 microempresa & 40,6 & 74,9 & 71,1 & 64,4 & 2,3 & 31,0 & 24,1 & 11,8 \\
\hline $10-49$ & 41,3 & 18,7 & 17,7 & 24,5 & 10,1 & 19,3 & 19,8 & 13,3 \\
\hline $50-199 \ldots$ & 13,7 & 4,9 & 6,8 & 7,9 & 21,2 & 17,9 & 20,6 & 20,2 \\
\hline $200-249$ & 1,1 & 0,4 & 0,7 & 0,7 & 5,1 & 2,4 & 2,1 & 4,1 \\
\hline 0-249 pyme & 96,7 & 98,8 & 96,3 & 97,5 & 38,7 & 70,6 & 66,6 & 49,4 \\
\hline $250-499$ & 2,1 & 0,7 & 1,6 & 1,3 & 12,8 & 6,7 & 6,8 & 10,7 \\
\hline 500 o más & 1,2 & 0,5 & 2,1 & 1,2 & 48,5 & 22,8 & 26,6 & 39,9 \\
\hline$>=250$ gran empresa $\ldots$ & 3,3 & 1,2 & 3,7 & 2,5 & 61,3 & 29,4 & 33,4 & 50,6 \\
\hline Total declarado DIRCE & 100,0 & 100,0 & 100,0 & 100,0 & 100,0 & 100,0 & 100,0 & 100,0 \\
\hline \multirow{2}{*}{ Estrato de asalariados } & \multicolumn{4}{|c|}{$\begin{array}{l}\text { Valor medio exportado por empresas } \\
\text { (millones de euros) }\end{array}$} & & & & \\
\hline & $\begin{array}{l}\text { Industria } \\
\text { (BCDE) }\end{array}$ & $\begin{array}{l}\text { Comercio } \\
(G)\end{array}$ & Resto & Total & & & & \\
\hline 0-9 microempresa & 0,4 & 0,8 & 0,1 & 0,5 & & & & \\
\hline $10-49$ & 1,6 & 2,0 & 0,4 & 1,4 & & & & \\
\hline $50-199$ & 10,0 & 6,9 & 1,0 & 6,9 & & & & \\
\hline $200-249$ & 28,9 & 12,8 & 0,9 & 16,3 & & & & \\
\hline 0-249 pyme & 2,6 & 1,4 & 0,2 & 1,4 & & & & \\
\hline $250-499$ & 39,4 & 18,9 & 1,4 & 21,5 & & & & \\
\hline 500 o más & 266,5 & 79,3 & 4,2 & 90,7 & & & & \\
\hline$>=250$ gran empresa $\ldots$ & 121,0 & 46,0 & 3,0 & 53,9 & & & & \\
\hline Total declarado DIRCE & 6,5 & 1,9 & 0,3 & 2,7 & & & & \\
\hline
\end{tabular}

a las de comercio, aunque dentro de estas las empresas de comercio al por mayor mostraron una regularidad muy superior a la media, mientras que la regularidad de las de comercio al por menor fue muy inferior. En el cruce del sector con el tamaño, la mayor parte del valor exportado en la industria lo realizaron las grandes empresas, mientras que en el comercio las pymes dominaron, con especial presencia de las microempresas. 


\section{Análisis de la concentración de las exportaciones por principales empresas exportadoras DIRCE}

Las principales empresas exportadoras DIRCE representan un porcentaje muy elevado de las exportaciones. Esta elevada concentración se repite con independencia de la zona de destino de la exportación (UE o extra UE) o de la actividad principal de las empresas (industria, comercio o resto).
Así, en 2018 las mil principales empresas exportadoras DIRCE concentraron más de dos tercios de la exportación (67,6\%), porcentaje similar al de los años anteriores, pero inferior al correspondiente al año 2010 (70,7\%). Asimismo, las cincuenta principales empresas exportadoras fueron responsables de más de una tercera parte de las exportaciones $(33,9 \%)$, porcentaje similar al correspondiente al del año precedente $(33,7 \%)$ y al del año $2010(34,0 \%)$ (Cuadro 8).

CUADRO 8

CONCENTRACIÓN DE LAS EXPORTACIONES (COMERCIO DECLARADO) DE LAS EMPRESAS DIRCE POR ZONA DE INTERCAMBIO

\begin{tabular}{|c|c|c|c|c|c|c|c|c|c|}
\hline \multirow{2}{*}{ Núm. empresas DIRCE } & \multicolumn{4}{|c|}{ Valor (millones de euros) } & \multicolumn{5}{|c|}{$\begin{array}{c}\text { Porcentaje sobre el total de cada zona } \\
\text { de intercambio }\end{array}$} \\
\hline & 2010 & 2015 & 2017 & 2018 & 2010 & 2015 & 2017 & 2018 & $\begin{array}{c}\text { Variación } \\
2018 / 2017 \text { (pp) }\end{array}$ \\
\hline \multicolumn{10}{|c|}{ Total } \\
\hline 5 principales empresas & 20.477 & 26.070 & 28.540 & 28.792 & 11,9 & 11,4 & 11,4 & 11,1 & $-0,3$ \\
\hline 10 principales empresas & 29.613 & 39.427 & 41.857 & 43.737 & 17,2 & 17,2 & 16,7 & 16,8 & 0,2 \\
\hline 20 principales empresas ......... & 41.158 & 55.164 & 59.813 & 61.953 & 23,9 & 24,1 & 23,8 & 23,9 & 0,0 \\
\hline 50 principales empresas ......... & 58.581 & 77.514 & 84.682 & 88.007 & 34,0 & 33,9 & 33,7 & 33,9 & 0,2 \\
\hline 100 principales empresas & 71.335 & 93.201 & 102.937 & 106.280 & 41,4 & 40,7 & 41,0 & 40,9 & $-0,1$ \\
\hline 500 principales empresas ......... & 105.212 & 133.961 & 147.254 & 152.455 & 61,1 & 58,5 & 58,7 & 58,7 & 0,0 \\
\hline 1.000 principales empresas .......... & 121.719 & 154.328 & 169.538 & 175.696 & 70,7 & 67,4 & 67,5 & 67,6 & 0,1 \\
\hline Total empresas DIRCE & 172.255 & 228.932 & 251.069 & 259.749 & 100,0 & 100,0 & 100,0 & 100,0 & - \\
\hline \multicolumn{10}{|c|}{ Unión Europea } \\
\hline 5 principales empresas ......... & 14.964 & 20.241 & 22.243 & 21.769 & 12,8 & 13,5 & 13,3 & 12,5 & $-0,7$ \\
\hline 10 principales empresas & 20.864 & 29.895 & 33.076 & 33.305 & 17,9 & 19,9 & 19,7 & 19,2 & $-0,5$ \\
\hline 20 principales empresas ......... & 27.489 & 39.929 & 45.205 & 45.250 & 23,6 & 26,6 & 26,9 & 26,1 & $-0,9$ \\
\hline 50 principales empresas ........ & 37.471 & 52.880 & 61.105 & 62.242 & 32,2 & 35,3 & 36,4 & 35,9 & $-0,6$ \\
\hline 100 principales empresas ......... & 45.641 & 62.748 & 72.469 & 73.668 & 39,2 & 41,9 & 43,2 & 42,5 & $-0,7$ \\
\hline 500 principales empresas ......... & 68.359 & 90.032 & 102.213 & 105.010 & 58,7 & 60,1 & 60,9 & 60,5 & $-0,4$ \\
\hline 1.000 principales empresas ......... & 79.904 & 103.868 & 117.409 & 120.961 & 68,6 & 69,3 & 70,0 & 69,7 & $-0,3$ \\
\hline Total empresas DIRCE & 116.524 & 149.887 & 167.768 & 173.524 & 100,0 & 100,0 & 100,0 & 100,0 & - \\
\hline \multicolumn{10}{|c|}{ Terceros países } \\
\hline 5 principales empresas & 5.513 & 8.384 & 9.099 & 10.112 & 9,9 & 10,6 & 10,9 & 11,7 & 0,8 \\
\hline 10 principales empresas & 8.749 & 13.642 & 13.430 & 14.823 & 15,7 & 17,3 & 16,1 & 17,2 & 1,1 \\
\hline 20 principales empresas ......... & 13.669 & 19.809 & 19.131 & 21.165 & 24,5 & 25,1 & 23,0 & 24,5 & 1,6 \\
\hline 50 principales empresas ........ & 21.110 & 28.488 & 28.986 & 30.752 & 37,9 & 36,1 & 34,8 & 35,7 & 0,9 \\
\hline 100 principales empresas ......... & 25.694 & 35.031 & 35.961 & 37.994 & 46,1 & 44,4 & 43,2 & 44,1 & 0,9 \\
\hline 500 principales empresas & 36.854 & 50.813 & 52.799 & 55.227 & 66,1 & 64,4 & 63,4 & 64,0 & 0,7 \\
\hline 1.000 principales empresas ......... & 41.816 & 57.904 & 60.280 & 62.994 & 75,0 & 73,4 & 72,4 & 73,1 & 0,7 \\
\hline Total empresas DIRCE & 55.731 & 78.904 & 83.301 & 86.225 & 100,0 & 100,0 & 100,0 & 100,0 & - \\
\hline
\end{tabular}


CUADRO 9

CONCENTRACIÓN DE LAS EXPORTACIONES (COMERCIO DECLARADO) DE LAS EMPRESAS DIRCE POR NÚMERO DE EMPRESASY ACTIVIDAD PRINCIPAL EN 2018

\begin{tabular}{|c|c|c|c|c|c|c|c|c|}
\hline \multirow[b]{2}{*}{ Núm. de empresas DIRCE } & \multicolumn{4}{|c|}{ Valor de las exportaciones (millones de euros) } & \multicolumn{4}{|c|}{ Porcentaje sobre total actividad } \\
\hline & $\begin{array}{c}\text { Industria } \\
\text { (BCDE) }\end{array}$ & $\begin{array}{c}\text { Comercio } \\
\text { (G) }\end{array}$ & $\begin{array}{c}\text { Resto } \\
\text { actividades }\end{array}$ & Total & $\begin{array}{c}\text { Industria } \\
\text { (BCDE) }\end{array}$ & $\begin{array}{l}\text { Comercio } \\
\text { (G) }\end{array}$ & $\begin{array}{c}\text { Resto } \\
\text { actividades }\end{array}$ & Total \\
\hline 5 principales empresas .... & 25.812 & 15.539 & 2.103 & 28.792 & 15,1 & 19,7 & 22,3 & 11,1 \\
\hline 10 principales empresas .... & 38.287 & 20.663 & 2.890 & 43.737 & 22,4 & 26,2 & 30,6 & 16,8 \\
\hline 20 principales empresas .... & 52.816 & 26.971 & 3.601 & 61.953 & 30,8 & 34,1 & 38,1 & 23,9 \\
\hline 50 principales empresas .... & 69.796 & 34.037 & 4.746 & 88.007 & 40,7 & 43,1 & 50,3 & 33,9 \\
\hline 100 principales empresas .... & 81.446 & 39.630 & 5.650 & 106.280 & 47,5 & 50,2 & 59,8 & 40,9 \\
\hline 500 principales empresas .... & 115.254 & 53.844 & 7.781 & 152.455 & 67,3 & 68,1 & 82,4 & 58,7 \\
\hline 1.000 principales empresas ... & 132.229 & 60.409 & 8.576 & 175.696 & 77,2 & 76,5 & 90,8 & 67,6 \\
\hline Total empresas DIRCE ... & 171.297 & 79.009 & 9.443 & 259.749 & 100,0 & 100,0 & 100,0 & 100,0 \\
\hline
\end{tabular}

La concentración se puede analizar según la zona de destino, ya sea comercio intra UE o extra UE. Así, el comercio intracomunitario muestra una mayor concentración de las exportaciones hasta las cincuenta primeras empresas, muy similar en las cien primeras e inferior a medida que aumenta el número de empresas principales.

Por actividades económicas (Cuadro 9), en 2018 las quinientas principales empresas tanto en el conjunto de la industria (secciones $B, C$, D y E de la CNAE 2009) como en el comercio (sección $\mathrm{G}$ ) fueron responsables de algo más de dos tercios de las exportaciones de cada sector $(67,3 \%$ en la industria y $68,1 \%$ en el comercio).

Por debajo de ese número de empresas del comercio presentaron un mayor grado de concentración en las exportaciones, mientras que, por encima, las mil principales de la industria presentaron un mayor porcentaje en las exportaciones (77,2\% frente al $76,5 \%$ del comercio). Más de la mitad de las exportaciones de comercio declarado de empresas DIRCE $(50,9 \%)$ fueron realizadas por las mil principales empresas de la industria.

\section{Análisis de la empresa exportadora DIRCE por actividad económica y tramo de exportación}

Como ya se mostraba en el epígrafe anterior, un reducido número de empresas concentra un gran volumen de exportaciones, con especial protagonismo de las grandes empresas de la industria.

En este epígrafe se llega a conclusiones similares mediante el estudio de los diferentes tramos de exportación.

Así, en 2018, los 293 exportadores DIRCE, que exportaron más de 100 millones de euros ese año, fueron responsables de más de la mitad de las exportaciones DIRCE (52,4\%), por importe de 135.988 millones, a pesar de representar únicamente el $0,3 \%$ del total de empresas. En perspectiva, en 2018 hubo siete empresas más que el año anterior que exportaron por encima de ese valor y 95 más que en 2010.

Por el contrario, por número de empresas exportadoras, el grueso se concentró en el tramo inferior (exportaciones por debajo de los 100.000 euros), con 67.666 empresas DIRCE en 2018 que, a pesar de suponer un 69,8\% $\square$ 
CUADRO 10

NÚMERO DE EMPRESAS EXPORTADORAS DIRCE Y VALOR DE SUS EXPORTACIONES POR TRAMOS DE EXPORTACIÓN

\begin{tabular}{|c|c|c|c|c|c|c|c|c|c|c|}
\hline \multirow{2}{*}{$\begin{array}{l}\text { Tramo de exportación } \\
\text { en euros }\end{array}$} & \multicolumn{5}{|c|}{ Número de empresas exportadoras DIRCE } & \multicolumn{5}{|c|}{ Valor de las exportaciones (millones de euros) } \\
\hline & 2010 & 2015 & 2017 & 2018 & $\begin{array}{c}\text { Variación } \\
2018 / 2017(\%)\end{array}$ & 2010 & 2015 & 2017 & 2018 & $\begin{array}{c}\text { Variación } \\
2018 / 2017(\%)\end{array}$ \\
\hline Menos de $100.000 .$. & 45.392 & 66.054 & 64.495 & 67.666 & 4,9 & 702 & 796 & 773 & 767 & $-0,7$ \\
\hline $100.000-249.999$ & 5.569 & 5.889 & 5.737 & 5.597 & $-2,4$ & 916 & 956 & 926 & 908 & $-2,0$ \\
\hline $250.000-499.999$ & 4.833 & 4.800 & 4.427 & 4.326 & $-2,3$ & 1.749 & 1.743 & 1.613 & 1.574 & $-2,4$ \\
\hline $500.000-999.999$. & 4.616 & 5.084 & 4.964 & 4.813 & $-3,0$ & 3.313 & 3.654 & 3.585 & 3.462 & $-3,4$ \\
\hline $1.000 .000-9.999 .999$ & 9.326 & 10.933 & 11.236 & 11.294 & 0,5 & 29.815 & 34.925 & 36.694 & 37.136 & 1,2 \\
\hline $10.000 .000-99.999 .999$. & 2.113 & 2.675 & 2.865 & 2.923 & 2,0 & 55.652 & 70.005 & 76.615 & 79.914 & 4,3 \\
\hline Más de 100.000.000 & 198 & 268 & 286 & 293 & 2,4 & 80.108 & 116.853 & 130.863 & 135.988 & 3,9 \\
\hline Total . & 72.047 & 95.703 & 94.010 & 96.912 & 3,1 & 172.255 & 228.932 & 251.069 & 259.749 & 3,5 \\
\hline \multirow{2}{*}{$\begin{array}{l}\text { Tramo de exportación } \\
\text { en euros }\end{array}$} & \multicolumn{5}{|c|}{$\begin{array}{l}\text { Porcentaje sobre el total de empresas } \\
\text { exportadoras DIRCE }\end{array}$} & \multicolumn{5}{|c|}{$\begin{array}{l}\text { Porcentaje sobre el total de exportaciones de las } \\
\text { empresas DIRCE }\end{array}$} \\
\hline & 2010 & 2015 & 2017 & 2018 & $\begin{array}{c}\text { Variación } \\
2018 / 2017(p p)\end{array}$ & 2010 & 2015 & 2017 & 2018 & $\begin{array}{l}\text { Variación } \\
2018 / 2017(p p)\end{array}$ \\
\hline Menos de 100.000 & 63,0 & 69,0 & 68,6 & 69,8 & 1,2 & 0,4 & 0,3 & 0,3 & 0,3 & 0,0 \\
\hline $100.000-249.999$ & 7,7 & 6,2 & 6,1 & 5,8 & $-0,3$ & 0,5 & 0,4 & 0,4 & 0,3 & 0,0 \\
\hline $250.000-499.999 \ldots$ & 6,7 & 5,0 & 4,7 & 4,5 & $-0,2$ & 1,0 & 0,8 & 0,6 & 0,6 & 0,0 \\
\hline $500.000-999.999$ & 6,4 & 5,3 & 5,3 & 5,0 & $-0,3$ & 1,9 & 1,6 & 1,4 & 1,3 & $-0,1$ \\
\hline $1.000 .000-9.999 .999$ & 12,9 & 11,4 & 12,0 & 11,7 & $-0,3$ & 17,3 & 15,3 & 14,6 & 14,3 & $-0,3$ \\
\hline $10.000 .000-99.999 .999$ & 2,9 & 2,8 & 3,0 & 3,0 & $-0,0$ & 32,3 & 30,6 & 30,5 & 30,8 & 0,3 \\
\hline Más de 100.000 .000 . & 0,3 & 0,3 & 0,3 & 0,3 & $-0,0$ & 46,5 & 51,0 & 52,1 & 52,4 & 0,2 \\
\hline Total & 100,0 & 100,0 & 100,0 & 100,0 & - & 100,0 & 100,0 & 100,0 & 100,0 & - \\
\hline
\end{tabular}

del total de exportadores, contribuyeron con apenas un $0,3 \%$ al total de las exportaciones (Cuadro 11).

En la evolución reciente se observa un incremento de la concentración de las exportaciones en los tramos superiores. Así, en 2018 los exportadores de más de 10 millones representaron el $83,1 \%$ de las exportaciones, 0,5 puntos porcentuales más que en 2017 y 4,3 más que en 2010.

Las empresas industriales tienen mayor peso en los tramos superiores de exportación que las de comercio. Así, en el Cuadro 11 se observa que en 2018 prácticamente la mitad de las empresas exportadoras DIRCE de la industria $(49,7 \%)$ exportó más de 100.000 euros, frente a solo el $31,5 \%$ del comercio. Estas mismas empresas aglutinaron el $99,9 \%$ del valor exportado por la industria y el $99,5 \%$ del comercio.

Además, la industria concentró a más del $70 \%$ de las empresas exportadoras DIRCE de más de 100 millones (204 de las 293), que fueron responsables de más de la mitad de las exportaciones de las empresas industriales DIRCE $(55,7 \%)$ y de más de un tercio de las exportaciones de comercio declarado DIRCE $(36,7 \%)$. 
Subdirección General de Estudios y Evaluación de Instrumentos de Política Comercial

CUADRO 11

NÚMERO DE EMPRESAS EXPORTADORAS DIRCE Y VALOR DE SUS EXPORTACIONES POR TRAMOS Y ACTIVIDAD PRINCIPAL EN 2018

\begin{tabular}{|c|c|c|c|c|c|c|c|c|}
\hline \multirow{2}{*}{$\begin{array}{l}\text { Tramos de exportación } \\
\text { en euros }\end{array}$} & \multicolumn{4}{|c|}{ Número de empresas exportadoras DIRCE } & \multicolumn{4}{|c|}{ Valor de las exportaciones (millones de euros) } \\
\hline & $\begin{array}{l}\text { Industria } \\
\text { (BCDE) }\end{array}$ & $\begin{array}{l}\text { Comercio } \\
\text { (G) }\end{array}$ & $\begin{array}{l}\text { Resto } \\
\text { actividades }\end{array}$ & Total & $\begin{array}{l}\text { Industria } \\
\text { (BCDE) }\end{array}$ & $\begin{array}{l}\text { Comercio } \\
\text { (G) }\end{array}$ & $\begin{array}{c}\text { Resto } \\
\text { actividades }\end{array}$ & Total \\
\hline Menos de 100.000 & 13.308 & 28.546 & 25.812 & 67.666 & 227 & 383 & 157 & 767 \\
\hline $100.000-249.999 \ldots$ & 1.929 & 2.750 & 918 & 5.597 & 314 & 447 & 146 & 908 \\
\hline $250.000-499.999$ & 1.669 & 2.083 & 574 & 4.326 & 612 & 757 & 205 & 1.574 \\
\hline $500.000-999.999$ & 1.994 & 2.303 & 516 & 4.813 & 1.440 & 1.651 & 372 & 3.462 \\
\hline $1.000 .000-9.999 .999$ & 5.418 & 5.024 & 852 & 11.294 & 18.766 & 15.855 & 2.515 & 37.136 \\
\hline $10.000 .000-99.999 .999 \ldots$ & 1.928 & 871 & 124 & 2.923 & 54.520 & 22.237 & 3.157 & 79.914 \\
\hline Más de 100.000.000 & 204 & 79 & 10 & 293 & 95.418 & 37.679 & 2.890 & 135.988 \\
\hline Total ... & 26.450 & 41.656 & 28.806 & 96.912 & 171.297 & 79.009 & 9.443 & 259.749 \\
\hline \multirow{2}{*}{$\begin{array}{l}\text { Tramos de exportación } \\
\text { en euros }\end{array}$} & \multicolumn{4}{|c|}{$\begin{array}{c}\text { Porcentaje sobre las empresas exportadoras } \\
\text { DIRCE de cada actividad }\end{array}$} & \multicolumn{4}{|c|}{$\begin{array}{l}\text { Porcentaje sobre las exportaciones de } \\
\text { empresas DIRCE de cada actividad }\end{array}$} \\
\hline & $\begin{array}{l}\text { Industria } \\
\text { (BCDE) }\end{array}$ & $\begin{array}{l}\text { Comercio } \\
\text { (G) }\end{array}$ & $\begin{array}{c}\text { Resto } \\
\text { actividades }\end{array}$ & Total & $\begin{array}{l}\text { Industria } \\
\text { (BCDE) }\end{array}$ & $\begin{array}{l}\text { Comercio } \\
\text { (G) }\end{array}$ & $\begin{array}{c}\text { Resto } \\
\text { actividades }\end{array}$ & Total \\
\hline Menos de 100.000 & 50,3 & 68,5 & 89,6 & 69,8 & 0,1 & 0,5 & 1,7 & 0,3 \\
\hline $100.000-249.999 \ldots$ & 7,3 & 6,6 & 3,2 & 5,8 & 0,2 & 0,6 & 1,6 & 0,3 \\
\hline $250.000-499.999$ & 6,3 & 5,0 & 2,0 & 4,5 & 0,4 & 1,0 & 2,2 & 0,6 \\
\hline $500.000-999.999$ & 7,5 & 5,5 & 1,8 & 5,0 & 0,8 & 2,1 & 3,9 & 1,3 \\
\hline $1.000 .000-9.999 .999$ & 20,5 & 12,1 & 3,0 & 11,7 & 11,0 & 20,1 & 26,6 & 14,3 \\
\hline $10.000 .000-99.999 .999 \ldots$ & 7,3 & 2,1 & 0,4 & 3,0 & 31,8 & 28,1 & 33,4 & 30,8 \\
\hline Más de 100.000 .000 & 0,8 & 0,2 & 0,0 & 0,3 & 55,7 & 47,7 & 30,6 & 52,4 \\
\hline Total ... & 100,0 & 100,0 & 100,0 & 100,0 & 100,0 & 100,0 & 100,0 & 100,0 \\
\hline
\end{tabular}

\section{Análisis de la empresa exportadora DIRCE por destino geográfico de las exportaciones}

En el análisis de los destinos geográficos conviene recordar el distinto tratamiento entre el comercio declarado extracomunitario y el intracomunitario, puesto que en este último no se incluye el comercio bajo umbral que, aun no siendo muy significativo en el valor de las exportaciones, sí lo es en lo que respecta al número de empresas (mayor detalle en el anexo metodológico). Dicho esto, la UE es el destino al que exportan más empresas españolas si se tiene en consideración el comercio total, que incluye la estimación del comercio bajo umbral, pero no si se tiene solo en cuenta el comercio declarado. Dentro de esta área destacan como principales destinos Francia, Portugal, Italia, Alemania y Reino Unido. Entre los destinos extracomunitarios a los que exportan más empresas españolas destacan EE UU, Suiza, China, Marruecos y México. Si se atiende al valor de lo exportado, Francia, dentro de la UE, y EE UU, entre los países no comunitarios, figuran como nuestros principales mercados.

Así, cuando se toma en consideración el comercio total DIRCE, que sí incluye la estimación del comercio bajo umbral, se observa que en 2018 había más empresas que exportaban a la UE que fuera de ella, 120.963 frente a 88.136. Si el análisis se restringe únicamente al comercio declarado, el número de exportadores que lo hicieron a la UE y que superaron el umbral de exención es mucho menor (27.273). No $\square$ 
obstante, el impacto del valor de las exportaciones bajo umbral (a la UE) es limitado. Prueba de ello es que las empresas de comercio declarado DIRCE exportaron por valor de 259.749 millones de euros en 2018 , lo que representa el $98,4 \%$ de las exportaciones totales realizadas por las empresas DIRCE, 263.879 millones de euros (Cuadro 1B).
Teniendo en cuenta estas salvedades y en términos de comercio declarado DIRCE, se observa que en 2018 las exportaciones a la UE representaron más de dos tercios del total $(66,8 \%)$ y fueron realizadas por 27.273 empresas (Cuadro 12). De estas empresas, más de dos tercios (18.497) habían exportado al mismo tiempo fuera de la Unión Europea. Como $\triangleright$

CUADRO 12

NÚMERO DE EMPRESAS EXPORTADORAS (DIRCE) Y VALOR DE SUS EXPORTACIONES POR ÁREA GEOGRÁFICA

\begin{tabular}{|c|c|c|c|c|c|c|c|c|c|c|}
\hline \multirow[b]{2}{*}{ Área geográfica } & \multicolumn{5}{|c|}{ Número de empresas exportadoras DIRCE } & \multicolumn{5}{|c|}{ Valor de las exportaciones (millones de euros) } \\
\hline & 2010 & 2015 & 2017 & 2018 & $\begin{array}{c}\text { Variación } \\
2018 / 2017(\%)\end{array}$ & 2010 & 2015 & 2017 & 2018 & $\begin{array}{c}\text { Variación } \\
\text { 2018/2017 (\%) }\end{array}$ \\
\hline UE. & 26.142 & 27.620 & 27.133 & 27.273 & 0,5 & 116.524 & 150.028 & 167.768 & 173.524 & 3,4 \\
\hline Extra UE ... & 62.880 & 86.979 & 85.409 & 88.136 & 3,2 & 55.731 & 78.904 & 83.301 & 86.225 & 3,5 \\
\hline Países europeos no UE.. & 29.256 & 35.706 & 37.077 & 37.683 & 1,6 & 12.155 & 12.966 & 14.052 & 14.442 & 2,8 \\
\hline Norte de África ... & 15.945 & 17.363 & 16.684 & 17.159 & 2,8 & 6.768 & 10.028 & 10.632 & 11.846 & 11,4 \\
\hline Otros países africanos & 10.264 & 15.914 & 15.115 & 15.116 & 0,0 & 2.658 & 3.716 & 3.632 & 3.322 & $-8,5$ \\
\hline América del Norte. & 12.295 & 24.776 & 24.076 & 24.649 & 2,4 & 7.110 & 11.279 & 12.715 & 13.195 & 3,8 \\
\hline América Central y Caribe .............. & 12.036 & 18.629 & 19.319 & 18.858 & $-2,4$ & 4.309 & 6.734 & 6.947 & 7.122 & 2,5 \\
\hline América del Sur...... & 14.408 & 21.822 & 22.152 & 24.471 & 10,5 & 5.430 & 7.459 & 7.447 & 7.310 & $-1,8$ \\
\hline Oriente Próximo y Medio ................ & 10.353 & 15.614 & 15.005 & 14.660 & $-2,3$ & 4.464 & 8.376 & 7.789 & 7.615 & $-2,2$ \\
\hline Otros países asiáticos & 14.371 & 24.897 & 26.042 & 25.960 & $-0,3$ & 8.300 & 13.487 & 15.062 & 15.503 & 2,9 \\
\hline Oceanía y las regiones polares ... & 4.080 & 6.570 & 7.241 & 7.501 & 3,6 & 1.170 & 1.388 & 1.572 & 1.564 & $-0,5$ \\
\hline País no UE indeterminado ............ & 977 & 1.134 & 1.091 & 1.260 & 15,5 & 3.368 & 3.472 & 3.453 & 4.306 & 24,7 \\
\hline Total mundial .. & 72.047 & 95.703 & 94.010 & 96.912 & 3,1 & 172.255 & 228.932 & 251.069 & 259.749 & 3,5 \\
\hline \multirow[b]{2}{*}{ Área geográfica } & \multicolumn{5}{|c|}{$\begin{array}{l}\text { Porcentaje sobre el total de empresas } \\
\text { exportadoras DIRCE }\end{array}$} & \multicolumn{5}{|c|}{$\begin{array}{l}\text { Porcentaje sobre el total de exportaciones } \\
\text { de empresas DIRCE }\end{array}$} \\
\hline & 2010 & 2015 & 2017 & 2018 & $\begin{array}{c}\text { Variación } \\
2018 / 2017 \\
\text { (pp) }\end{array}$ & 2010 & 2015 & 2017 & 2018 & $\begin{array}{c}\text { Variación } \\
2018 / 2017 \\
\text { (pp) }\end{array}$ \\
\hline UE. & 36,3 & 28,9 & 28,9 & 28,1 & $-0,7$ & 67,6 & 65,5 & 66,8 & 66,8 & 0,0 \\
\hline Extra UE . & 87,3 & 90,9 & 90,9 & 90,9 & 0,1 & 32,4 & 34,5 & 33,2 & 33,2 & 0,0 \\
\hline Extra UE. & \multicolumn{5}{|c|}{$\begin{array}{l}\text { Porcentaje sobre el total de empresas } \\
\text { exportadoras DIRCE extra UE }\end{array}$} & \multicolumn{5}{|c|}{$\begin{array}{l}\text { Porcentaje sobre el total de exportaciones } \\
\text { de empresas DIRCE extra UE }\end{array}$} \\
\hline Países europeos no UE .... & 46,5 & 41,1 & 43,4 & 42,8 & $-0,7$ & 21,8 & 16,4 & 16,9 & 16,7 & $-0,1$ \\
\hline Norte de África & 25,4 & 20,0 & 19,5 & 19,5 & $-0,1$ & 12,1 & 12,7 & 12,8 & 13,7 & 1,0 \\
\hline Otros países africanos & 16,3 & 18,3 & 17,7 & 17,2 & $-0,5$ & 4,8 & 4,7 & 4,4 & 3,9 & $-0,5$ \\
\hline América del Norte & 19,6 & 28,5 & 28,2 & 28,0 & $-0,2$ & 12,8 & 14,3 & 15,3 & 15,3 & 0,0 \\
\hline América Central y Caribe ................ & 19,1 & 21,4 & 22,6 & 21,4 & $-1,2$ & 7,7 & 8,5 & 8,3 & 8,3 & $-0,1$ \\
\hline América del Sur... & 22,9 & 25,1 & 25,9 & 27,8 & 1,8 & 9,7 & 9,5 & 8,9 & 8,5 & $-0,5$ \\
\hline Oriente Próximo y Medio & 16,5 & 18,0 & 17,6 & 16,6 & $-0,9$ & 8,0 & 10,6 & 9,4 & 8,8 & $-0,5$ \\
\hline Otros países asiáticos & 22,9 & 28,6 & 30,5 & 29,5 & $-1,0$ & 14,9 & 17,1 & 18,1 & 18,0 & $-0,1$ \\
\hline Oceanía y las regiones polares ... & 6,5 & 7,6 & 8,5 & 8,5 & 0,0 & 2,1 & 1,8 & 1,9 & 1,8 & $-0,1$ \\
\hline País no UE indeterminado ............. & 1,6 & 1,3 & 1,3 & 1,4 & 0,2 & 6,0 & 4,4 & 4,1 & 5,0 & 0,8 \\
\hline
\end{tabular}


se ha señalado, estas cifras excluyen tanto a las empresas exportadoras como a las operaciones que no superan el umbral Intrastat.

Por su parte, el comercio extracomunitario representó en 2018 el 33,2\% del total de las exportaciones y fue realizado por $83.136 \mathrm{em}$ presas en 2018. Dentro de este ámbito, el área geográfica a la que exportaron un mayor número de empresas DIRCE fue la de los países europeos no UE, el 42,8\% del total extra UE, seguida por Asia (excepto Oriente Medio y Próximo), América del Norte y América del Sur, con el $29,5 \%, 28,0 \%$ y $27,8 \%$, respectivamente, del total extra UE. Entre los años 2010 y 2018 destaca el incremento del número de empresas DIRCE que exportaron a América del Norte y a Asia (excepto Oriente Medio y Próximo) y también en el peso sobre el valor de las exportaciones extra UE, pero con el orden cambiado.

En términos de valor, las exportaciones extracomunitarias de las empresas DIRCE se concentraron, por este orden, en Asia (excepto Oriente Medio y Próximo), países europeos no UE, América del Norte y Norte de África, con un peso sobre el total extra UE de $18,0 \%$, $16,7 \%, 15,3 \%$ y $13,7 \%$, respectivamente.

En el Cuadro 13 se muestran las exportaciones de comercio declarado de empresas DIRCE por países, separando, por un lado, a los países de la Unión Europea y, por otro, a una selección de países extracomunitarios. Dentro de la UE, el $61,9 \%$ de las empresas DIRCE (comercio declarado) que exportaron a esa zona de intercambio tuvo entre sus destinos a Francia, seguida por Portugal, con el $56,4 \%$, e Italia y Alemania, con valores muy similares (46,8\% y 46,3\%, respectivamente).

Con respecto al valor exportado a la UE por empresas DIRCE, Francia volvió a dominar con el $23,3 \%$ del total UE, seguida por
Alemania $(16,9 \%)$, Italia $(11,9 \%)$, Portugal $(11,4 \%)$ y Reino Unido $(10,1 \%)$.

Con respecto al comercio declarado extracomunitario realizado por empresas DIRCE, el destino al que exportó un mayor número de empresas fue Estados Unidos, con 22.958 empresas en 2018 , el $26,0 \%$ de las empresas DIRCE que exportaron fuera de la UE. Le siguieron Suiza (18,0\%), China (14,6\%), Marruecos (14,2\%) y México (13,5\%). En cuanto al valor exportado, el primer destino extracomunitario fue nuevamente Estados Unidos, con el $13,4 \%$ de las exportaciones fuera de la UE, seguido por Marruecos $(7,2 \%)$, China $(5,7 \%)$, Turquía $(5,1 \%)$ y México $(5,0 \%)$.

Con respecto a la exportación media por empresa, el análisis se realiza de nuevo de forma independiente para las dos zonas de intercambio (UE y extra UE), ya que los datos no son comparables por incluir únicamente el comercio declarado.

Así, las empresas DIRCE de comercio declarado que exportaron a la UE tuvieron una exportación intracomunitaria media de 6,4 millones de euros (dato muy influenciado por el umbral de exención de 400.000 euros en 2018). Los destinos que mostraron un mayor valor medio de exportación por empresa y país fueron Alemania y Francia, ambos con una cifra superior a los 2,3 millones de euros. Le siguieron Italia (1,61 millones), Reino Unido (1,60 millones) y Portugal (1,29 millones).

En lo que respecta a las empresas DIRCE que realizaron exportaciones extracomunitarias, las exportaciones medias a esa área fueron de 978.300 euros y los destinos con mayor valor medio de exportación por empresa y país fueron Argelia, con una exportación media de 741.800 euros, seguido por Turquía (611.700), Arabia Saudí (529.500), EE UU (504.800) y Marruecos (491.900). 
CUADRO 13

NÚMERO DE EMPRESAS EXPORTADORAS DIRCE POR PAÍSES Y ZONAS (UE / EXTRA UE) Y VALOR DE SUS EXPORTACIONES (ORDENADO DE MÁS A MENOS EXPORTACIONES EN 2018)

\begin{tabular}{|c|c|c|c|c|c|c|c|c|c|}
\hline \multicolumn{10}{|c|}{ Países de la Unión Europea } \\
\hline \multirow{2}{*}{$\begin{array}{l}\text { País } \\
\text { UE }\end{array}$} & \multicolumn{4}{|c|}{$\begin{array}{c}\text { Número de empresas exportadoras } \\
\text { DIRCE }\end{array}$} & \multicolumn{4}{|c|}{$\begin{array}{l}\text { Valor de las exportaciones } \\
\text { (millones de euros) }\end{array}$} & \multirow{2}{*}{$\begin{array}{c}2018 \\
\text { Exportación } \\
\text { media por } \\
\text { empresa (miles } \\
\text { de euros) }\end{array}$} \\
\hline & 2017 & 2018 & $\begin{array}{c}\text { Variación } \\
2018 / 2017 \\
(\%)\end{array}$ & $\begin{array}{c}2018 \\
\% \text { s. } \\
\text { total UE }\end{array}$ & 2017 & 2018 & $\begin{array}{c}\text { Variación } \\
2018 / 2017 \\
(\%)\end{array}$ & $\begin{array}{c}2018 \\
\% \text { s. } \\
\text { total UE }\end{array}$ & \\
\hline Francia ........... & 16.788 & 16.882 & 0,6 & 61,9 & 38.546 & 40.406 & 4,8 & 23,3 & $2.393,5$ \\
\hline Alemania .... & 12.715 & 12.623 & $-0,7$ & 46,3 & 29.289 & 29.311 & 0,1 & 16,9 & $2.322,0$ \\
\hline Italia & 12.691 & 12.762 & 0,6 & 46,8 & 19.964 & 20.581 & 3,1 & 11,9 & $1.612,7$ \\
\hline 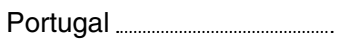 & 15.425 & 15.372 & $-0,3$ & 56,4 & 18.606 & 19.797 & 6,4 & 11,4 & $1.287,9$ \\
\hline Reino Unido & 10.927 & 10.923 & $-0,0$ & 40,1 & 17.757 & 17.502 & $-1,4$ & 10,1 & $1.602,3$ \\
\hline Países Bajos ... & 9.228 & 9.271 & 0,5 & 34,0 & 8.635 & 9.305 & 7,8 & 5,4 & $1.003,7$ \\
\hline Bélgica ........... & 8.469 & 8.487 & 0,2 & 31,1 & 7.716 & 7.617 & $-1,3$ & 4,4 & 897,5 \\
\hline Polonia ............ & 7.167 & 7.262 & 1,3 & 26,6 & 5.180 & 5.343 & 3,2 & 3,1 & 735,8 \\
\hline República Checa .... & 5.286 & 5.416 & 2,5 & 19,9 & 2.264 & 2.305 & 1,8 & 1,3 & 425,6 \\
\hline Austria ............. & 4.586 & 4.664 & 1,7 & 17,1 & 2.180 & 2.178 & $-0,1$ & 1,3 & 467,1 \\
\hline Suecia & 4.511 & 4.531 & 0,4 & 16,6 & 2.082 & 2.083 & 0,0 & 1,2 & 459,6 \\
\hline Grecia & 4.681 & 4.752 & 1,5 & 17,4 & 1.949 & 2.059 & 5,7 & 1,2 & 433,3 \\
\hline 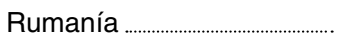 & 4.642 & 4.730 & 1,9 & 17,3 & 1.819 & 2.010 & 10,5 & 1,2 & 424,9 \\
\hline Dinamarca & 4.419 & 4.407 & $-0,3$ & 16,2 & 1.534 & 1.700 & 10,8 & 1,0 & 385,8 \\
\hline Hungría & 3.684 & 3.814 & 3,5 & 14,0 & 1.532 & 1.685 & 10,0 & 1,0 & 441,7 \\
\hline Irlanda & 3.703 & 3.765 & 1,7 & 13,8 & 1.196 & 1.220 & 2,0 & 0,7 & 323,9 \\
\hline Eslovaquia & 2.785 & 2.903 & 4,2 & 10,6 & 950 & 1.030 & 8,5 & 0,6 & 354,9 \\
\hline Finlandia & 3.273 & 3.293 & 0,6 & 12,1 & 817 & 862 & 5,6 & 0,5 & 261,8 \\
\hline Eslovenia & 2.459 & 2.463 & 0,2 & 9,0 & 556 & 616 & 10,8 & 0,4 & 250,1 \\
\hline Bulgaria ........ & 3.256 & 3.395 & 4,3 & 12,4 & 532 & 558 & 4,8 & 0,3 & 164,3 \\
\hline Croacia & 1.974 & 2.112 & 7,0 & 7,7 & 413 & 418 & 1,3 & 0,2 & 198,1 \\
\hline Malta & 2.122 & 2.143 & 1,0 & 7,9 & 334 & 380 & 13,8 & 0,2 & 177,3 \\
\hline Lituania ..... & 2.709 & 2.755 & 1,7 & 10,1 & 384 & 364 & $-5,2$ & 0,2 & 132,1 \\
\hline Chipre & 2.054 & 2.073 & 0,9 & 7,6 & 252 & 266 & 5,2 & 0,2 & 128,1 \\
\hline Luxemburgo .......................................... & 1.652 & 1.725 & 4,4 & 6,3 & 273 & 245 & $-10,5$ & 0,1 & 141,8 \\
\hline Estonia ... & 2.088 & 2.105 & 0,8 & 7,7 & 226 & 227 & 0,2 & 0,1 & 107,6 \\
\hline Letonia & 2.021 & 2.059 & 1,9 & 7,5 & 197 & 216 & 9,5 & 0,1 & 104,7 \\
\hline País UE inderterminado ........ & 1.391 & 1.533 & 10,2 & 5,6 & 2.585 & 3.241 & 25,4 & 1,9 & $2.114,5$ \\
\hline Total UE & 27.133 & 27.273 & 0,5 & 100,0 & 167.768 & 173.524 & 3,4 & 100,0 & $6.362,5$ \\
\hline \multicolumn{10}{|c|}{ Selección de países extra-UE } \\
\hline País & \multicolumn{4}{|c|}{$\begin{array}{l}\text { Número de empresas exportadoras } \\
\text { DIRCE }\end{array}$} & \multicolumn{4}{|c|}{$\begin{array}{l}\text { Valor de las exportaciones } \\
\text { (millones de euros) }\end{array}$} & $\begin{array}{c}2018 \\
\text { Exportación }\end{array}$ \\
\hline Extra-UE & 2017 & 2018 & $\begin{array}{c}\text { Variación } \\
2018 / 2017 \\
(\%)\end{array}$ & $\begin{array}{c}2018 \\
\% \text { s. } \\
\text { total UE }\end{array}$ & 2017 & 2018 & $\begin{array}{c}\text { Variación } \\
2018 / 2017 \\
(\%)\end{array}$ & $\begin{array}{c}2018 \\
\% \text { s. } \\
\text { total UE }\end{array}$ & $\begin{array}{c}\text { media por } \\
\text { empresa (miles } \\
\text { de euros) }\end{array}$ \\
\hline Estados Unidos & 22.459 & 22.958 & 2,2 & 26,0 & 11.342 & 11.589 & 2,2 & 13,4 & 504,8 \\
\hline Marruecos & 12.489 & 12.545 & 0,4 & 14,2 & 6.075 & 6.172 & 1,6 & 7,2 & 491,9 \\
\hline China & 13.048 & 12.892 & $-1,2$ & 14,6 & 4.963 & 4.881 & $-1,7$ & 5,7 & 378,6 \\
\hline Turquía & 7.162 & 7.160 & 0,0 & 8,1 & 5.070 & 4.380 & $-13,6$ & 5,1 & 611,7 \\
\hline México …………………………………... & 12.042 & 11.917 & $-1,0$ & 13,5 & 4.299 & 4.318 & 0,4 & 5,0 & 362,3 \\
\hline Suiza & 15.544 & 15.879 & 2,2 & 18,0 & 3.652 & 3.733 & 2,2 & 4,3 & 235,1 \\
\hline Argelia & 4.272 & 4.245 & $-0,6$ & 4,8 & 2.400 & 3.149 & 31,2 & 3,7 & 741,8 \\
\hline Japón .... & 6.652 & 6.798 & 2,2 & 7,7 & 2.212 & 2.266 & 2,5 & 2,6 & 333,3 \\
\hline
\end{tabular}


Subdirección General de Estudios y Evaluación de Instrumentos de Política Comercial

CUADRO 13

NÚMERO DE EMPRESAS EXPORTADORAS DIRCE POR PAÍSES Y ZONAS (UE / EXTRA UE) Y VALOR DE SUS EXPORTACIONES (ORDENADO DE MÁS A MENOS EXPORTACIONES EN 2018) (cont.)

\begin{tabular}{|c|c|c|c|c|c|c|c|c|c|}
\hline \multicolumn{10}{|c|}{ Selección de países extra-UE } \\
\hline \multirow{2}{*}{$\begin{array}{c}\text { País } \\
\text { Extra-UE }\end{array}$} & \multicolumn{4}{|c|}{$\begin{array}{c}\text { Número de empresas exportadoras } \\
\text { DIRCE }\end{array}$} & \multicolumn{4}{|c|}{$\begin{array}{l}\text { Valor de las exportaciones (millones de } \\
\text { euros) }\end{array}$} & \multirow{2}{*}{$\begin{array}{c}2018 \\
\text { Exportación } \\
\text { media por } \\
\text { empresa (miles } \\
\text { de euros) }\end{array}$} \\
\hline & 2017 & 2018 & $\begin{array}{c}\text { Variación } \\
2018 / 2017 \\
\text { (\%) }\end{array}$ & $\begin{array}{c}2018 \\
\% \text { S. } \\
\text { total UE }\end{array}$ & 2017 & 2018 & $\begin{array}{c}\text { Variación } \\
2018 / 2017 \\
\text { (\%) }\end{array}$ & $\begin{array}{c}2018 \\
\% \text { s. } \\
\text { total UE }\end{array}$ & \\
\hline Arabia Saudí . & 4.342 & 4.158 & $-4,2$ & 4,7 & 2.117 & 2.202 & 4,0 & 2,6 & 529,5 \\
\hline 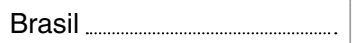 & 5.369 & 5.162 & $-3,9$ & 5,9 & 2.158 & 2.086 & $-3,3$ & 2,4 & 404,1 \\
\hline Federación de Rusia & 4.532 & 4.615 & 1,8 & 5,2 & 1.770 & 1.883 & 6,4 & 2,2 & 407,9 \\
\hline República de Corea & 4.830 & 4.861 & 0,6 & 5,5 & 1.598 & 1.873 & 17,2 & 2,2 & 385,3 \\
\hline Canadá & 6.903 & 7.292 & 5,6 & 8,3 & 1.373 & 1.555 & 13,2 & 1,8 & 213,2 \\
\hline Chile ............................. & 8.011 & 7.991 & $-0,2$ & 9,1 & 1.289 & 1.440 & 11,7 & 1,7 & 180,2 \\
\hline Egipto & 3.132 & 3.469 & 10,8 & 3,9 & 1.061 & 1.423 & 34,1 & 1,7 & 410,2 \\
\hline Emiratos Árabes Unidos ..... & 6.685 & 6.334 & $-5,3$ & 7,2 & 1.458 & 1.405 & $-3,7$ & 1,6 & 221,8 \\
\hline Israel ................................................ & 5.584 & 5.703 & 2,1 & 6,5 & 1.358 & 1.341 & $-1,2$ & 1,6 & 235,2 \\
\hline Australia ... & 6.165 & 6.421 & 4,2 & 7,3 & 1.305 & 1.306 & 0,1 & 1,5 & 203,5 \\
\hline India & 5.925 & 6.031 & 1,8 & 6,8 & 1.178 & 1.217 & 3,3 & 1,4 & 201,8 \\
\hline Noruega & 6.031 & 6.276 & 4,1 & 7,1 & 956 & 1.069 & 11,9 & 1,2 & 170,4 \\
\hline Argentina & 5.319 & 5.091 & $-4,3$ & 5,8 & 1.202 & 1.069 & $-11,1$ & 1,2 & 209,9 \\
\hline Sudáfrica & 4.134 & 4.047 & $-2,1$ & 4,6 & 1.079 & 1.002 & $-7,1$ & 1,2 & 247,5 \\
\hline Singapur ................. & 3.946 & 4.064 & 3,0 & 4,6 & 519 & 931 & 79,5 & 1,1 & 229,1 \\
\hline Hong Kong & 6.409 & 6.247 & $-2,5$ & 7,1 & 921 & 837 & $-9,2$ & 1,0 & 134,0 \\
\hline Túnez & 3.545 & 3.384 & $-4,5$ & 3,8 & 769 & 739 & $-3,8$ & 0,9 & 218,5 \\
\hline Tailandia & 2.850 & 2.973 & 4,3 & 3,4 & 582 & 612 & 5,1 & 0,7 & 205,8 \\
\hline Rep. Islámica de Irán & 1.866 & 1.362 & $-27,0$ & 1,5 & 388 & 510 & 31,3 & 0,6 & 374,3 \\
\hline Malasia & 2.441 & 2.569 & 5,2 & 2,9 & 638 & 508 & $-20,3$ & 0,6 & 197,9 \\
\hline Taiwán & 3.916 & 4.068 & 3,9 & 4,6 & 463 & 423 & $-8,6$ & 0,5 & 104,0 \\
\hline Indonesia & 1.844 & 1.888 & 2,4 & 2,1 & 427 & 417 & $-2,5$ & 0,5 & 220,6 \\
\hline Vietnam ................. & 2.408 & 2.382 & $-1,1$ & 2,7 & 392 & 389 & $-1,0$ & 0,5 & 163,1 \\
\hline Qatar & 2.408 & 2.336 & $-3,0$ & 2,7 & 392 & 364 & $-7,2$ & 0,4 & 155,9 \\
\hline Ucrania & 2.588 & 2.736 & 5,7 & 3,1 & 314 & 338 & 8,0 & 0,4 & 123,7 \\
\hline Nigeria & 1.896 & 2.192 & 15,6 & 2,5 & 208 & 268 & 29,2 & 0,3 & 122,5 \\
\hline Kazajstán & 1.000 & 925 & $-7,5$ & 1,0 & 159 & 113 & $-29,1$ & 0,1 & 121,9 \\
\hline Islandia & 1.135 & 1.202 & 5,9 & 1,4 & 50 & 51 & 1,2 & 0,1 & 42,4 \\
\hline Total extra UE ... & 85.409 & 88.136 & 3,2 & 100,0 & 83.301 & 86.225 & 3,5 & 100,0 & 978,3 \\
\hline Total mundial & 94.010 & 96.912 & 3,1 & - & 251.069 & 259.749 & 3,5 & - & $2.680,3$ \\
\hline
\end{tabular}

\section{Número de empresas exportadoras DIRCE por número de destinos}

Aunque la mayor parte de las empresas DIRCE exportan a un solo país de destino, las empresas que exportan a múltiples destinos son las que contribuyen en mayor medida al valor total de las exportaciones.
En 2018 más de la mitad de las empresas exportadoras DIRCE de comercio declarado (51,9\%) exportaron a un único país, si bien en términos del valor de las exportaciones apenas representaron el 2,2\% del total.

En el extremo opuesto, las 5.995 empresas que exportaron en el año 2018 a veinte o más destinos (el 6,2\% del total) fueron responsables del $68,8 \%$ de las exportaciones (Cuadro 14). $\triangleright$ 
CUADRO 14

NÚMERO DE EMPRESAS EXPORTADORAS (DIRCE) Y VALOR DE SUS EXPORTACIONES POR NÚMERO DE PAÍSES CONTRAPARTIDA

\begin{tabular}{|c|c|c|c|c|c|c|c|c|c|c|}
\hline \multirow{2}{*}{$\begin{array}{l}\mathrm{N} .^{\circ} \text { de } \\
\text { países }\end{array}$} & \multicolumn{5}{|c|}{ Número de empresas exportadoras DIRCE } & \multicolumn{5}{|c|}{ Valor de las exportaciones (millones de euros) } \\
\hline & 2010 & 2015 & 2017 & 2018 & $\begin{array}{c}\text { Variación } \\
\text { 2018/2017 (\%) }\end{array}$ & 2010 & 2015 & 2017 & 2018 & $\begin{array}{c}\text { Variación } \\
\text { 2018/2017 (\%) }\end{array}$ \\
\hline 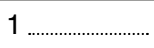 & 37.656 & 49.928 & 47.705 & 50.295 & 5,4 & 5.698 & 5.525 & 5.867 & 5.837 & $-0,5$ \\
\hline $2 \ldots$ & 9.659 & 12.977 & 12.844 & 13.014 & 1,3 & 4.559 & 4.318 & 4.053 & 4.426 & 9,2 \\
\hline $3-5 \ldots \ldots \ldots \ldots$ & 10.410 & 13.628 & 13.801 & 13.855 & 0,4 & 11.343 & 11.038 & 11.964 & 11.608 & $-3,0$ \\
\hline $6-9$ & 5.275 & 7.011 & 7.076 & 7.138 & 0,9 & 13.185 & 14.416 & 17.171 & 16.873 & $-1,7$ \\
\hline $10-14$ & 3.242 & 4.101 & 4.201 & 4.172 & $-0,7$ & 18.658 & 15.555 & 17.867 & 20.743 & 16,1 \\
\hline $15-19$ & 1.874 & 2.365 & 2.450 & 2.443 & $-0,3$ & 13.392 & 20.088 & 22.143 & 21.564 & $-2,6$ \\
\hline 20 o más & 3.931 & 5.693 & 5.933 & 5.995 & 1,0 & 105.419 & 157.992 & 172.004 & 178.700 & 3,9 \\
\hline Total . & 72.047 & 95.703 & 94.010 & 96.912 & 3,1 & 172.255 & 228.932 & 251.069 & 259.749 & 3,5 \\
\hline \multicolumn{11}{|c|}{ Porcentaje sobre el total de la columna } \\
\hline $\begin{array}{l}\mathrm{N} .^{\circ} \text { de } \\
\text { países }\end{array}$ & 2010 & 2015 & 2017 & 2018 & $\begin{array}{l}\text { Variación } \\
2018 / 2017 \text { (pp) }\end{array}$ & 2010 & 2015 & 2017 & 2018 & $\begin{array}{c}\text { Variación } \\
\text { 2018/2017 (pp) }\end{array}$ \\
\hline 1 ............................. & 52,3 & 52,2 & 50,7 & 51,9 & 1,2 & 3,3 & 2,4 & 2,3 & 2,2 & $-0,1$ \\
\hline $2 \ldots \ldots \ldots \ldots \ldots \ldots \ldots \ldots$ & 13,4 & 13,6 & 13,7 & 13,4 & $-0,2$ & 2,6 & 1,9 & 1,6 & 1,7 & 0,1 \\
\hline $3-5 \ldots \ldots \ldots \ldots \ldots$ & 14,4 & 14,2 & 14,7 & 14,3 & $-0,4$ & 6,6 & 4,8 & 4,8 & 4,5 & $-0,3$ \\
\hline $6-9$ & 7,3 & 7,3 & 7,5 & 7,4 & $-0,2$ & 7,7 & 6,3 & 6,8 & 6,5 & $-0,3$ \\
\hline $10-14$ & 4,5 & 4,3 & 4,5 & 4,3 & $-0,2$ & 10,8 & 6,8 & 7,1 & 8,0 & 0,9 \\
\hline $15-19$ & 2,6 & 2,5 & 2,6 & 2,5 & $-0,1$ & 7,8 & 8,8 & 8,8 & 8,3 & $-0,5$ \\
\hline 20 o más & 5,5 & 5,9 & 6,3 & 6,2 & $-0,1$ & 61,2 & 69,0 & 68,5 & 68,8 & 0,3 \\
\hline Total & 100,0 & 100,0 & 100,0 & 100,0 & - & 100,0 & 100,0 & 100,0 & 100,0 & - \\
\hline
\end{tabular}

\section{Características de la empresa exportadora con datos de Eurostat}

Los datos de Eurostat ${ }^{5}$ cruzan los operadores de comercio total (no únicamente del comercio declarado) con el directorio de empresas de cada país. Este hecho, junto con otras diferencias metodológicas, hace que sus datos para España difieran de los datos de Aduanas analizados en los epígrafes anteriores. Así, en 2018, con los datos de Eurostat, el número de empresas españolas que cruzaban con el directorio ascendía a $167.408^{6}$ (frente a las 96.912 empresas DIRCE

5 Salvo indicación en contrario, los datos de Eurostat presentados en este apartado proceden de la operación estadística: International trade in goods - trade by enterprise characteristics (TEC) (ext_tec).

6 La cifra de 2018 no coincide por diferencias metodológicas con la equivalente que Aduanas ofrece para España de comercio total DIRCE en el Cuadro 1A. calculadas por Aduanas con comercio declarado) y realizaron exportaciones por 266.927 millones (frente a los 259.749 calculados por Aduanas). En la comparación de estos datos se observa que si bien la diferencia del valor exportado es poco significativa (inferior al $3 \%$ ), la del número de empresas sí es muy destacable, puesto que Eurostat toma en consideración la estimación de 70.496 empresas del comercio intracomunitario bajo umbral que cruzaban con el DIRCE y que para Aduanas no forman parte del análisis.

La comparación de España frente a los principales países exportadores de la UE7, atendiendo al tamaño de las empresas exportadoras según el número de asalariados $\triangleright$

7 Se seleccionan los diez principales países exportadores de la UE atendiendo al valor de las exportaciones de la operación estadística de Eurostat: EU28 trade by SITC product group (ext_st_eu28sitc). 
Subdirección General de Estudios y Evaluación de Instrumentos de Política Comercial

CUADRO 15A

NÚMERO DE EMPRESAS EXPORTADORAS POR ESTRATO DE ASALARIADOS EN 2018 (10 PRINCIPALES EXPORTADORES DE LA UE)

\begin{tabular}{|c|c|c|c|c|c|c|}
\hline \multirow[b]{2}{*}{ País } & \multicolumn{6}{|c|}{ Número de empresas exportadoras del directorio de empresas* } \\
\hline & $\begin{array}{c}0 \text { a } 9 \\
\text { asalariados } \\
\text { micro }\end{array}$ & $\begin{array}{c}10 \text { a } 49 \\
\text { asalariados } \\
\text { pequeña }\end{array}$ & $\begin{array}{c}50 \text { a } 249 \\
\text { asalariados } \\
\text { mediana }\end{array}$ & $\begin{array}{c}\text { Total pyme } \\
\text { ( } 0 \text { a } 249 \\
\text { asalariados) }\end{array}$ & $\begin{array}{c}>=250 \\
\text { asalariados } \\
\text { grande }\end{array}$ & $\begin{array}{l}\text { Total empresas } \\
\text { directorio }\end{array}$ \\
\hline Alemania & 173.271 & 58.690 & 22.582 & 254.543 & 7.217 & 261.760 \\
\hline Países Bajos ............ & 87.768 & 16.693 & 5.267 & 109.728 & 1.342 & 111.070 \\
\hline 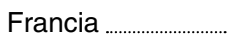 & 53.829 & 21.384 & 7.975 & 83.188 & 3.402 & 86.590 \\
\hline Italia & 123.691 & 54.420 & 11.183 & 189.294 & 2.086 & 191.380 \\
\hline Reino Unido & 94.369 & 34.018 & 11.105 & 139.492 & 3.701 & 143.193 \\
\hline España & 121.402 & 33.920 & 9.486 & 164.808 & 2.600 & 167.408 \\
\hline Polonia ...... & 90.048 & 26.176 & 8.954 & 125.178 & 2.648 & 127.826 \\
\hline Rep. Checa .... & 6.245 & 5.703 & 3.629 & 15.577 & 1.250 & 16.827 \\
\hline Austria .... & 27.591 & 9.434 & 2.870 & 39.895 & 1.024 & 40.919 \\
\hline Suecia .... & 33.626 & 9.259 & 2.947 & 45.832 & 945 & 46.777 \\
\hline \multirow[t]{3}{*}{ UE } & 1.004 .644 & 340.351 & 108.966 & 1.453 .961 & 32.261 & 1.486 .222 \\
\hline & \multicolumn{6}{|c|}{ Porcentaje sobre el total de empresas exportadoras del directorio de empresas* } \\
\hline & $\begin{array}{c}0 \text { a } 9 \\
\text { asalariados } \\
\text { micro }\end{array}$ & $\begin{array}{c}10 \text { a } 49 \\
\text { asalariados } \\
\text { pequeña }\end{array}$ & $\begin{array}{c}50 \text { a } 249 \\
\text { asalariados } \\
\text { mediana }\end{array}$ & $\begin{array}{c}\text { Total pyme } \\
\text { (0 a } 249 \\
\text { asalariados) }\end{array}$ & $\begin{array}{c}>=250 \\
\text { asalariados } \\
\text { grande }\end{array}$ & $\begin{array}{l}\text { Total empresas } \\
\text { directorio }\end{array}$ \\
\hline Alemania & 66,2 & 22,4 & 8,6 & 97,2 & 2,8 & 100,0 \\
\hline Países Bajos ............ & 79,0 & 15,0 & 4,7 & 98,8 & 1,2 & 100,0 \\
\hline Francia & 62,2 & 24,7 & 9,2 & 96,1 & 3,9 & 100,0 \\
\hline Italia & 64,6 & 28,4 & 5,8 & 98,9 & 1,1 & 100,0 \\
\hline Reino Unido & 65,9 & 23,8 & 7,8 & 97,4 & 2,6 & 100,0 \\
\hline España & 72,5 & 20,3 & 5,7 & 98,4 & 1,6 & 100,0 \\
\hline Polonia & 70,4 & 20,5 & 7,0 & 97,9 & 2,1 & 100,0 \\
\hline Rep. Checa & 37,1 & 33,9 & 21,6 & 92,6 & 7,4 & 100,0 \\
\hline Austria & 67,4 & 23,1 & 7,0 & 97,5 & 2,5 & 100,0 \\
\hline Suecia $\ldots . .$. & 71,9 & 19,8 & 6,3 & 98,0 & 2,0 & 100,0 \\
\hline UE $\ldots$ & 67,6 & 22,9 & 7,3 & 97,8 & 2,2 & 100,0 \\
\hline \multicolumn{7}{|c|}{$\begin{array}{l}\text { * Solo se incluyen las empresas que se han podido cruzar con el directorio de empresas de cada país, por lo que se excluyen los unknown en termino } \\
\text { logía de Eurostat. }\end{array}$} \\
\hline
\end{tabular}

(Cuadros 15A y 15B), muestra una mayor presencia de las pymes exportadoras en España, derivada del mayor peso de las microempresas. Además, las pymes españolas también contribuyen al valor exportado con un porcentaje superior a la media de la $U^{8}$ y a la mayor parte de los países analizados. Por otro lado, el

8 Dentro de la UE28, ni Bélgica ni Estonia presentan datos para 2018 en el momento de elaborar este artículo; por los datos que hacen referencia a la UE, no incluyen a estos dos países. Aunque Bélgica se encuentra entre los diez principales exportadores de la UE, no se ha podido tomar en consideración por esta misma razón. valor medio exportado por las empresas españolas es inferior al del conjunto de la UE en todos los tramos de tamaño.

Los datos analizados permiten también explorar la relevancia de determinados factores que inciden en la probabilidad y capacidad de exportar. Así, los datos relativos a la propiedad de las empresas (Cuadro 17) confirman la importancia de la contribución al valor de la exportación de las empresas que o bien están controladas por capital extranjero o bien, estando bajo control nacional, disponen de $D$ 
CUADRO 15B

NÚMERO DE EMPRESAS EXPORTADORAS POR ESTRATO DE ASALARIADOS EN 2018 (10 PRINCIPALES EXPORTADORES DE LA UE)

\begin{tabular}{|c|c|c|c|c|c|c|c|}
\hline \multirow[b]{2}{*}{ País } & \multicolumn{6}{|c|}{$\begin{array}{l}\text { Exportaciones de empresas exportadoras del directorio de empresas* } \\
\text { (Millones de euros) }\end{array}$} & \multirow{2}{*}{$\begin{array}{l}\text { Exportaciones } \\
\text { totales }\end{array}$} \\
\hline & $\begin{array}{c}0 \text { a } 9 \\
\text { asalariados } \\
\text { micro }\end{array}$ & $\begin{array}{c}10 \text { a } 49 \\
\text { asalariados } \\
\text { pequeña }\end{array}$ & $\begin{array}{l}50 \text { a } 249 \\
\text { asalariados } \\
\text { mediana }\end{array}$ & $\begin{array}{c}\text { Total pyme } \\
\text { (0 a } 249 \\
\text { asalariados) }\end{array}$ & $\begin{array}{c}>=250 \\
\text { asalariados } \\
\text { grande }\end{array}$ & $\begin{array}{l}\text { Total empresas } \\
\text { directorio }\end{array}$ & \\
\hline Alemania ............ & 52.341 & 67.082 & 146.533 & 265.956 & 882.141 & 1.148 .098 & 1.320 .734 \\
\hline Países Bajos .. & 42.253 & 65.196 & 141.416 & 248.865 & 140.658 & 389.522 & 615.602 \\
\hline Francia & 16.487 & 27.844 & 44.739 & 89.071 & 317.792 & 406.862 & 492.965 \\
\hline Italia & 22.932 & 75.793 & 129.402 & 228.127 & 211.787 & 439.913 & 465.327 \\
\hline Reino Unido ... & 55.211 & 28.764 & 51.140 & 135.115 & 188.444 & 323.558 & 412.057 \\
\hline España & 34.568 & 36.607 & 63.907 & 135.082 & 131.844 & 266.927 & 293.460 \\
\hline Polonia & 10.579 & 14.649 & 31.167 & 56.395 & 114.498 & 170.894 & 223.214 \\
\hline Rep. Checa .... & 4.247 & 8.637 & 22.901 & 35.784 & 77.608 & 113.392 & 171.261 \\
\hline Austria & 17.685 & 11.377 & 27.399 & 56.462 & 90.641 & 147.103 & 156.430 \\
\hline Suecia & 20.862 & 11.743 & 24.057 & 56.662 & 79.562 & 136.224 & 140.552 \\
\hline \multirow[t]{3}{*}{ UE } & 326.187 & 414.549 & 831.038 & 1.571 .774 & 2.654.899 & 4.226 .673 & 5.075 .345 \\
\hline & \multicolumn{6}{|c|}{ Porcentaje sobre el total de empresas exportadoras del directorio de empresas } & \multirow{2}{*}{$\begin{array}{l}\% \text { exportadores } \\
\text { directorio s. } \\
\text { exportaciones } \\
\text { totales }\end{array}$} \\
\hline & $\begin{array}{c}0 \text { a } 9 \\
\text { asalariados } \\
\text { micro }\end{array}$ & $\begin{array}{c}10 \text { a } 49 \\
\text { asalariados } \\
\text { pequeña }\end{array}$ & $\begin{array}{c}50 \text { a } 249 \\
\text { asalariados } \\
\text { mediana }\end{array}$ & $\begin{array}{l}\text { Total pyme } \\
\text { ( } 0 \text { a } 249 \text { as.) }\end{array}$ & $\begin{array}{c}>=250 \\
\text { asalariados } \\
\text { grande }\end{array}$ & $\begin{array}{l}\text { Total empresas } \\
\text { directorio }\end{array}$ & \\
\hline Alemania ........... & 4,6 & 5,8 & 12,8 & 23,2 & 76,8 & 100,0 & 86,9 \\
\hline Países Bajos .. & 10,8 & 16,7 & 36,3 & 63,9 & 36,1 & 100,0 & 63,3 \\
\hline Francia ................ & 4,1 & 6,8 & 11,0 & 21,9 & 78,1 & 100,0 & 82,5 \\
\hline Italia & 5,2 & 17,2 & 29,4 & 51,9 & 48,1 & 100,0 & 94,5 \\
\hline Reino Unido ... & 17,1 & 8,9 & 15,8 & 41,8 & 58,2 & 100,0 & 78,5 \\
\hline España & 13,0 & 13,7 & 23,9 & 50,6 & 49,4 & 100,0 & 91,0 \\
\hline 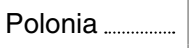 & 6,2 & 8,6 & 18,2 & 33,0 & 67,0 & 100,0 & 76,6 \\
\hline Rep. Checa .... & 3,7 & 7,6 & 20,2 & 31,6 & 68,4 & 100,0 & 66,2 \\
\hline Austria & 12,0 & 7,7 & 18,6 & 38,4 & 61,6 & 100,0 & 94,0 \\
\hline Suecia & 15,3 & 8,6 & 17,7 & 41,6 & 58,4 & 100,0 & 96,9 \\
\hline UE $\ldots$. & 7,7 & 9,8 & 19,7 & 37,2 & 62,8 & 100,0 & 83,3 \\
\hline \multirow[b]{2}{*}{ País } & \multicolumn{6}{|c|}{$\begin{array}{l}\text { Exportación media de las exportadoras del directorio de empresas } \\
\text { (Millones de euros) }\end{array}$} & \\
\hline & $\begin{array}{c}0 \text { a } 9 \\
\text { asalariados } \\
\text { micro }\end{array}$ & $\begin{array}{c}10 \text { a } 49 \\
\text { asalariados } \\
\text { pequeña }\end{array}$ & $\begin{array}{c}50 \text { a } 249 \\
\text { asalariados } \\
\text { mediana }\end{array}$ & $\begin{array}{c}\text { Total pyme } \\
\text { (0 a } 249 \\
\text { asalariados) }\end{array}$ & $\begin{array}{c}>=250 \\
\text { asalariados } \\
\text { grande }\end{array}$ & $\begin{array}{l}\text { Total empresas } \\
\text { directorio }\end{array}$ & \\
\hline Alemania & 0,30 & 1,14 & 6,49 & 1,04 & 122,23 & 4,39 & \\
\hline Países Bajos .. & 0,48 & 3,91 & 26,85 & 2,27 & 104,81 & 3,51 & \\
\hline Francia & 0,31 & 1,30 & 5,61 & 1,07 & 93,41 & 4,70 & \\
\hline Italia & 0,19 & 1,39 & 11,57 & 1,21 & 101,53 & 2,30 & \\
\hline Reino Unido ... & 0,59 & 0,85 & 4,61 & 0,97 & 50,92 & 2,26 & \\
\hline España & 0,28 & 1,08 & 6,74 & 0,82 & 50,71 & 1,59 & \\
\hline Polonia & 0,12 & 0,56 & 3,48 & 0,45 & 43,24 & 1,34 & \\
\hline Rep. Checa .... & 0,68 & 1,51 & 6,31 & 2,30 & 62,09 & 6,74 & \\
\hline 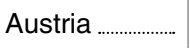 & 0,64 & 1,21 & 9,55 & 1,42 & 88,52 & 3,59 & \\
\hline Suecia & 0,62 & 1,27 & 8,16 & 1,24 & 84,19 & 2,91 & \\
\hline UE & 0,32 & 1,22 & 7,63 & 1,08 & 82,29 & 2,84 & \\
\hline
\end{tabular}


filiales en el exterior. Igualmente, se constata que la propensión a exportar de las empresas españolas aumenta con su tamaño y que es más elevada en el sector manufacturero y en la división del comercio al por mayor (Cuadro 19). Además, la mayor parte de las empresas que exportan realizan, a su vez, importaciones y son las empresas exportadoras-importadoras las que en mayor medida contribuyen al valor total de lo exportado (Cuadro 20).

Así, por lo que se refiere al tamaño de las empresas exportadoras, en España, en el año 2018 y con datos de Eurostat, el 98,4\% de las empresas exportadoras del directorio eran pymes (Cuadro 15A), cifra superior a la del conjunto de la UE $(97,8 \%)$, así como a la de Alemania, Francia y Reino Unido, aunque inferior a la de Italia. Ello es debido al mayor peso relativo que las microempresas presentaban en España, $72,5 \%$ frente al $67,6 \%$ en la UE, y, dentro de los diez principales exportadores, solo por debajo de Países Bajos. En cambio, tanto en las pequeñas como en las medianas empresas la proporción era menor en España que para la UE. Lo mismo ocurría para las grandes empresas, que suponían tan solo un $1,6 \%$ de las empresas exportadoras del directorio, por debajo del 2,2\% de la UE. Entre los principales exportadores solo en Italia y Países Bajos este porcentaje era menor.

Con respecto al valor de las exportaciones, en 2018 en el conjunto de la UE, las grandes empresas (250 o más asalariados) contribuyeron con el $62,8 \%$ al total de exportaciones de empresas del directorio (Cuadro 15B). Este dato está muy influenciado por la cifra de Alemania, el primer exportador de la UE, donde las grandes empresas aglutinaban el $76,8 \%$ de las exportaciones de empresas del directorio. En España el valor se situaba en el 49,4\% del total, siendo solo superior, entre los diez primeros países exportadores, al de Países Bajos e Italia. Por el contrario, en España más de la mitad de las exportaciones en 2018 las realizaron las pymes (50,6\%).

En el análisis de la exportación media por empresa exportadora del directorio, España se sitúa por debajo de la UE en todos los tramos. Así, la exportación media por empresa alcanzó los 1,59 millones, cifra significativamente inferior a la del conjunto de la UE (2,84 millones). De los diez principales países exportadores, tan solo la cifra de Polonia se situó por debajo (1,34 millones). Las mayores diferencias se produjeron en las grandes empresas exportadoras del directorio que, en España, exportaron de media 50,71 millones de euros, lejos de los 82,29 millones del conjunto de la UE y todavía más de los 122,23 millones de Alemania, 104,81 millones de Países Bajos o 101,53 millones de Italia.

El Cuadro 16 refleja la concentración de las exportaciones de las principales empresas exportadoras de una selección de países de la UE. Como puede apreciarse, en España las exportaciones de los mil mayores exportadores representaron algo menos de dos tercios de las exportaciones $(65,8 \%)$, el segundo porcentaje más bajo de los principales exportadores de la UE, solo por detrás de Italia $(51,1 \%$ ) y lejos de los valores correspondientes de Francia $(80,2 \%)$ y Reino Unido (76,6\%).

Por lo que se refiere a la propiedad nacional o extranjera de la empresa, en España, en 2018 había 7.843 empresas exportadoras DIRCE controladas por propietarios extranjeros, las cuales, a pesar de representar únicamente el $4,7 \%$ de las empresas exportadoras del directorio, fueron responsables del $39,4 \%$ del valor de las exportaciones. El resto de las exportaciones $(60,6 \%$ del total) fue realizado por empresas controladas por propietarios $\triangleright$ 
CUADRO 16

EXPORTACIONES DE LAS MAYORES EMPRESAS EXPORTADORAS EN 2018 (10 PRINCIPALES EXPORTADORES DE LA UE) (En millones de euros y porcentaje sobre las exportaciones totales)

\begin{tabular}{|c|c|c|c|c|c|c|c|c|}
\hline & Total valor & $\begin{array}{c}5 \\
\text { principales }\end{array}$ & $\begin{array}{c}10 \\
\text { principales }\end{array}$ & $\begin{array}{c}20 \\
\text { principales }\end{array}$ & $\begin{array}{c}50 \\
\text { principales }\end{array}$ & $\begin{array}{c}100 \\
\text { principales }\end{array}$ & $\begin{array}{c}500 \\
\text { principales }\end{array}$ & $\begin{array}{c}1.000 \\
\text { principales }\end{array}$ \\
\hline Alemania & 1.148 .098 & 21,4 & 26,8 & 32,1 & 38,9 & 44,1 & 59,1 & 66,7 \\
\hline Países Bajos .. & 389.522 & 11,4 & 16,9 & 22,8 & 32,4 & 41,0 & 63,2 & 73,0 \\
\hline Francia & 414.131 & 19,5 & 24,8 & 30,8 & 41,7 & 50,9 & 72,0 & 80,2 \\
\hline Italia & 439.913 & 6,2 & 8,9 & 12,9 & 19,5 & 25,7 & 42,6 & 51,8 \\
\hline Reino Unido ... & 323.558 & 17,7 & 23,5 & 30,9 & 42,6 & 50,6 & 68,9 & 76,6 \\
\hline España & 266.927 & 10,8 & 16,4 & 23,2 & 33,0 & 39,8 & 57,1 & 65,8 \\
\hline Polonia & 170.953 & 6,8 & 10,2 & 15,1 & 23,3 & 31,7 & 56,3 & 67,6 \\
\hline Rep. Checa .... & 115.223 & 18,4 & 21,5 & 25,6 & 33,3 & 40,7 & 63,4 & 73,9 \\
\hline Austria & 147.103 & 9,0 & 13,9 & 21,4 & 33,9 & 44,7 & 72,0 & 83,0 \\
\hline Suecia .................. & 136.224 & 18,6 & 24,9 & 34,3 & 47,6 & 57,9 & 78,5 & 86,4 \\
\hline
\end{tabular}

nacionales. El 30,6\% del total corresponde a empresas de capital nacional que no tienen filiales en el exterior (154.167 empresas) y el $29,9 \%$ a las que sí tienen (5.398 empresas). Es de destacar que estas últimas registraron unas exportaciones medias de 14,8 millones de euros, cifra incluso superior a la de la media de empresas controladas por propietarios extranjeros (13,4 millones) (Cuadro 17).

Eurostat también presenta estos mismos datos desglosados por países, aunque únicamente para trece Estados miembros (Cuadro 18). Entre estos, el porcentaje de las exportaciones realizadas por empresas controladas por propietarios nacionales en España $(60,6 \%)$ solo es superado por el correspondiente a
Alemania $(67,4 \%)$ y a Dinamarca $(67,3 \%)$. En el extremo opuesto se situarían Eslovaquia, Rumanía y República Checa, donde la mayor parte de sus exportaciones fueron realizadas por las empresas controladas por propietarios extranjeros, aglutinando respectivamente el $86,5 \%, 82,3 \%$ y $76,4 \%$ de sus exportaciones. Las empresas que o bien están bajo control extranjero o bien, estando bajo control nacional, tienen filiales en el extranjero, fueron responsables en España de más de dos terceras partes del comercio en 2018 (69,4\%), lo que es indicativo de una elevada integración de España en las cadenas globales de valor.

La propensión exportadora general de las empresas DIRCE en España, definida como $\triangleright$

CUADRO 17

ESPAÑA: EMPRESAS EXPORTADORAS POR TIPO DE PROPIEDAD EN 2018, NÚMERO Y VALOR DE EXPORTACIONES

\begin{tabular}{|c|c|c|c|c|c|}
\hline \multirow[b]{2}{*}{ Variable } & \multicolumn{3}{|c|}{ Empresas controladas por propietarios nacionales } & \multirow{2}{*}{$\begin{array}{l}\text { Empresas controladas } \\
\text { por propietarios } \\
\text { extranjeros }\end{array}$} & \multirow{2}{*}{$\begin{array}{l}\text { Total empresas } \\
\text { (directorio } \\
\text { empresas) }\end{array}$} \\
\hline & $\begin{array}{l}\text { Con filiales } \\
\text { en el extranjero }\end{array}$ & $\begin{array}{l}\text { Sin filiales } \\
\text { en el extranjero }\end{array}$ & $\begin{array}{c}\text { Total } \\
\text { nacionales }\end{array}$ & & \\
\hline Número & 5.398 & 154.167 & 159.565 & 7.843 & 167.408 \\
\hline$\%$ s. directorio ...... & 3,2 & 92,1 & 95,3 & 4,7 & 100,0 \\
\hline Millones de euros .... & 79.915 & 81.800 & 161.715 & 105.212 & 266.927 \\
\hline$\%$ s. directorio .......... & 29,9 & 30,6 & 60,6 & 39,4 & 100,0 \\
\hline Millones de euros / empresa ..... & 14,8 & 0,5 & 1,0 & 13,4 & 1,6 \\
\hline
\end{tabular}

Fuente: Eurostat. 
Subdirección General de Estudios y Evaluación de Instrumentos de Política Comercial

CUADRO 18

UE: EMPRESAS EXPORTADORAS POR TIPO DE PROPIEDAD EN 2018, PORCENTAJE SOBRE DIRECTORIO Y VALOR EXPORTADO

(Países con datos)

\begin{tabular}{|c|c|c|c|c|c|}
\hline \multirow[b]{2}{*}{ País } & \multicolumn{3}{|c|}{ Empresas controladas por propietarios nacionales (\%) } & \multirow{2}{*}{$\begin{array}{l}\text { Empresas controladas } \\
\text { por propietarios } \\
\text { extranjeros }(\%)\end{array}$} & \multirow{2}{*}{$\begin{array}{l}\text { Total empresas } \\
\text { del directorio } \\
\text { (Millones de euros) }\end{array}$} \\
\hline & $\begin{array}{c}\text { Con filiales en el } \\
\text { extranjero }\end{array}$ & $\begin{array}{c}\text { Sin filiales en el } \\
\text { extranjero }\end{array}$ & Total nacionales & & \\
\hline Alemania ................. & - & - & 67,4 & 32,6 & 1.057 .329 \\
\hline España & 29,9 & 30,6 & 60,6 & 39,4 & 266.927 \\
\hline Polonia & 7,8 & 35,9 & 43,7 & 56,3 & 170.953 \\
\hline Austria $\ldots \ldots \ldots \ldots \ldots \ldots \ldots$ & 22,2 & 35,0 & 57,1 & 42,9 & 147.103 \\
\hline Rep. Checa ........... & - & - & 23,6 & 76,4 & 115.223 \\
\hline Dinamarca ............... & 41,6 & 25,7 & 67,3 & 32,7 & 86.902 \\
\hline Eslovaquia & - & - & 13,5 & 86,5 & 67.316 \\
\hline Finlandia & 51,9 & 7,9 & 59,8 & 40,2 & 62.635 \\
\hline Rumanía & 1,1 & 16,6 & 17,7 & 82,3 & 58.408 \\
\hline Portugal ........................ & 17,6 & 41,4 & 59,0 & 41,0 & 52.718 \\
\hline Eslovenia & 26,7 & 25,5 & 52,2 & 47,8 & 27.546 \\
\hline Lituania & 8,3 & 43,8 & 52,1 & 47,9 & 21.890 \\
\hline Chipre & 20,1 & 24,3 & 44,4 & 55,6 & 3.862 \\
\hline
\end{tabular}

la proporción del número de empresas del directorio que exportan respecto al total, fue del $5,0 \%$ en 2018. Si se analiza esa misma ratio para cada tamaño de empresa, se observa, como parece razonable, que la probabilidad de que una empresa exporte aumenta con el tamaño. En 2018, tan solo el $3,8 \%$ de las microempresas exportaron, frente al $58,4 \%$ de las grandes empresas. La propensión exportadora de las pymes fue del 4,9\% (Cuadro 19).

Dado que hay sectores que están claramente concentrados en el mercado nacional, conviene afinar este análisis distinguiendo según la actividad principal. Así, las empresas de la industria manufacturera (sección $\mathrm{C}$ de la CNAE 2009) registraron una propensión exportadora del $21,2 \%$, muy superior al 5,0\% del conjunto de la economía. Si se analizan las empresas de la industria manufacturera de más de diez asalariados, la propensión exportadora aumenta hasta el $63,7 \%$. En cuanto al comercio, y dentro de este, a la división del comercio al por mayor e intermediarios del comercio, la propensión aumenta hasta el $21,3 \%$, y si se restringe a empresas de más de diez asalariados, se incrementa hasta el $67,4 \%$.

Otro factor que parece determinante a la hora de exportar es si la empresa exportadora es también importadora. En el Cuadro 20 se muestran las estadísticas de los diez principales países exportadores de la UE. Así, en 2018 la práctica totalidad de las exportaciones españolas en 2018 (96,6\%) fueron realizadas por las empresas que realizaron al mismo tiempo actividades de exportación e importación (103.903 empresas, $62,1 \%$ del total de las exportadoras), quedando un valor residual del $3,4 \%$ para las 63.505 empresas exportadoras DIRCE que únicamente realizaron operaciones de exportación.

En el resto de principales países exportadores de la UE las empresas que exportan e importan al mismo tiempo también aglutinaron más del $95 \%$ de las exportaciones, si bien los pesos de estas empresas sobre el total de exportadores difieren. Estos datos son coherentes con la idea de que importar puede facilitar la actividad exportadora. Las razones de que así $\square$ 
CUADRO 19

ESPAÑA: NÚMERO DE EMPRESAS EXPORTADORAS DIRCE POR ESTRATO DE ASALARIADOS (COMERCIO TOTAL) EN 2018

\begin{tabular}{|c|c|c|c|c|c|}
\hline \multirow[b]{2}{*}{ Estrato de asalariados } & \multirow{2}{*}{$\begin{array}{l}\text { Empresas } \\
\text { exportadoras } \\
\text { directorio }\end{array}$} & \multirow{2}{*}{$\begin{array}{l}\text { Total } \\
\text { empresas } \\
\text { DIRCE }\end{array}$} & \multicolumn{2}{|c|}{ Porcentaje sobre total } & \multirow{2}{*}{$\begin{array}{c}\text { Porcentaje } \\
\text { exportadoras } \\
\text { sobre total DIRCE }\end{array}$} \\
\hline & & & $\begin{array}{c}\text { Empresas } \\
\text { exportadoras DIRCE }\end{array}$ & $\begin{array}{c}\text { Total empresas } \\
\text { DIRCE }\end{array}$ & \\
\hline 0 - 9 microempresa & 121.402 & 3.185 .314 & 72,5 & 95,4 & 3,8 \\
\hline 10 - 49 pequeña & 33.920 & 126.345 & 20,3 & 3,8 & 26,8 \\
\hline 50 - 249 mediana & 9.486 & 21.533 & 5,7 & 0,6 & 44,1 \\
\hline 0-249 pyme & 164.808 & 3.333.192 & 98,4 & 99,9 & 4,9 \\
\hline$>=250$ gran empresa $\ldots$ & 2.600 & 4.454 & 1,6 & 0,1 & 58,4 \\
\hline Total & 167.408 & 3.337 .646 & 100,0 & 100,0 & 5,0 \\
\hline \multicolumn{6}{|c|}{ Sector industrial } \\
\hline Industria manufacturera (CNAE C) ..... & 38.291 & 180.267 & 22,9 & 5,4 & 21,2 \\
\hline Total industria (CNAE B, C, D y E) ..... & 39.291 & 206.711 & 23,5 & 6,2 & 19,0 \\
\hline \multicolumn{6}{|c|}{ Sector industrial (más de 10 asalariados) } \\
\hline Industria manufacturera (CNAE C) ..... & 18.998 & 29.841 & 11,3 & 0,9 & 63,7 \\
\hline Total industria (CNAE B, C, D y E) ..... & 19.515 & 31.832 & 11,7 & 1,0 & 61,3 \\
\hline \multicolumn{6}{|c|}{ Sector comercio } \\
\hline Comercio al por mayor (G46) ............... & 47.186 & 221.018 & 28,2 & 6,6 & 21,3 \\
\hline Total comercio (sección G) .................... & 67.668 & 747.874 & 40,4 & 22,4 & 9,0 \\
\hline \multicolumn{6}{|c|}{ Sector comercio (más de 10 asalariados) } \\
\hline Comercio al por mayor (G46) & 10.049 & 14.911 & 6,0 & 0,4 & 67,4 \\
\hline Total comercio (sección G) .................... & 13.533 & 26.177 & 8,1 & 0,8 & 51,7 \\
\hline
\end{tabular}

\begin{tabular}{|c|c|c|c|c|c|c|}
\hline \multicolumn{7}{|c|}{$\begin{array}{c}\text { CUADRO } 20 \\
\text { EMPRESAS EXPORTADORAS SEGÚN TIPOLOGÍA EN 2018, PORCENTAJE SOBRE DIRECTORIO } \\
\text { (10 principales exportadores de la UE) }\end{array}$} \\
\hline \multirow[b]{2}{*}{ País } & \multicolumn{2}{|c|}{ Núm. empresas directorio } & \multicolumn{2}{|c|}{ Núm. empresas (\% s. directorio) } & \multicolumn{2}{|c|}{ Valor exportado (\% s. directorio) } \\
\hline & $\begin{array}{c}\text { Solo } \\
\text { exportadoras }\end{array}$ & $\begin{array}{l}\text { Exportadoras- } \\
\text { importadoras }\end{array}$ & $\begin{array}{c}\text { Solo } \\
\text { exportadoras }\end{array}$ & $\begin{array}{l}\text { Exportadoras- } \\
\text { importadoras }\end{array}$ & $\begin{array}{c}\text { Solo } \\
\text { exportadoras }\end{array}$ & $\begin{array}{l}\text { Exportadoras- } \\
\text { importadoras }\end{array}$ \\
\hline Alemania ................... & 68.179 & 193.581 & 26,0 & 74,0 & 1,1 & 98,9 \\
\hline Países Bajos .......... & 31.428 & 79.642 & 28,3 & 71,7 & 0,9 & 99,1 \\
\hline Francia & 55.744 & 48.303 & 53,6 & 46,4 & 2,8 & 97,2 \\
\hline Italia & 83.917 & 107.463 & 43,8 & 56,2 & 2,5 & 97,5 \\
\hline Reino Unido ............ & 51.535 & 91.658 & 36,0 & 64,0 & 2,8 & 97,2 \\
\hline España & 63.505 & 103.903 & 37,9 & 62,1 & 3,4 & 96,6 \\
\hline Polonia & 53.371 & 75.408 & 41,4 & 58,6 & 3,0 & 97,0 \\
\hline Rep. Checa & 6.390 & 11.793 & 35,1 & 64,9 & 4,0 & 96,0 \\
\hline Austria & 4.754 & 36.165 & 11,6 & 88,4 & 1,4 & 98,6 \\
\hline Suecia $\ldots \ldots \ldots \ldots \ldots \ldots \ldots \ldots \ldots . .$. & 12.382 & 34.395 & 26,5 & 73,5 & 5,0 & 95,0 \\
\hline
\end{tabular}

sea son variadas, como la mejora de la competitividad, al poder beneficiarse de un mercado de inputs mucho más amplio, o el mayor conocimiento de las redes y prácticas comerciales, así como de las preferencias de los consumidores de los países desde los que se importa, en el proceso conocido en la literatura académica como learning by importing. 


\section{Conclusiones}

A partir de los datos analizados de Aduanas (comercio declarado de empresas DIRCE) y Eurostat (comercio total de empresas del directorio) se puede extraer una serie de rasgos característicos de las empresas exportadoras españolas, cuyo conocimiento puede resultar de utilidad, tanto para comprender la dinámica de las exportaciones como para conocer mejor a la base exportadora y adaptar a sus características el diseño e implementación de las políticas de apoyo a la internacionalización de las empresas.

En primer lugar, y con respecto al tamaño, se observa que la inmensa mayoría de las empresas exportadoras DIRCE de comercio declarado son pymes (97,5\%), si bien sus exportaciones representan algo menos de la mitad del valor de las exportaciones $(49,4 \%)$, quedando el resto para un número reducido de grandes empresas. Precisamente en el análisis de la concentración se observa que más de dos tercios de las exportaciones se realizan por las mil primeras empresas exportadoras (67,6\% con datos de Aduanas).

Asimismo, conviene resaltar que la inmensa mayoría de las exportaciones, el 97,0\% del comercio declarado de empresas DIRCE en 2018, lo realizan empresas que exportan de manera regular. Aproximadamente la mitad de las empresas $(48,4 \%)$ son exportadoras regulares, proporción que ronda el $80 \%$ en las medianas y grandes empresas.

La mayor parte de las empresas exportadoras tienen como actividad principal o bien el comercio $(43,0 \%)$ o bien la industria manufacturera $(26,6 \%)$, siendo las empresas de estos dos sectores responsables de más del $95 \%$ de las exportaciones. En concreto, más de dos tercios para la industria manufacturera $(65,2 \%)$ y más de un $30 \%$ para el comercio. Las empresas en estas actividades presentan una mayor regularidad en sus exportaciones. Así, el $68,9 \%$ de las empresas de la industria manufacturera exportan de forma regular y, dentro del comercio, destacan por su regularidad las del comercio al por mayor, con el 59,4\%.

Por destinos geográficos, aproximadamente dos terceras partes del comercio declarado se dirige a la UE (66,8\% en 2018). Más de la mitad de las empresas exportadoras DIRCE de comercio declarado $(51,9 \%)$ exportan a un único destino, aunque con una incidencia mínima en las exportaciones (2,2\% del total). Por el contrario, el grueso de las exportaciones $(68,8 \%$ del total) fueron realizadas por las empresas que exportaron a veinte o más destinos $(6,2 \%$ del total).

La propensión a exportar de las empresas españolas aumenta muy significativamente con el tamaño y es notablemente superior en la industria y en el comercio al por mayor. Así, si la propensión a exportar para el conjunto de las empresas es del 5,0\%, aumenta hasta el $21,2 \%$ en la industria manufacturera y hasta el 21,3\% en la división del comercio al por mayor. Para las empresas de más de diez asalariados esta propensión aumenta hasta el $63,7 \%$ en la industria manufacturera y hasta el $67,4 \%$ en el comercio al por mayor.

En cuanto al control de las empresas, las controladas por propietarios extranjeros y las de propiedad nacional con filiales en el exterior son responsables de prácticamente un $70 \%$ de las exportaciones españolas. Así, las empresas controladas por propietarios extranjeros contribuyen con cerca del $40 \%$ al valor exportado. Dentro de las exportaciones realizadas por empresas controladas por propietarios nacionales (más del $60 \%$ del valor total) destacan, por su peso en las exportaciones, las empresas que tienen filiales en el exterior (que contribuyen con un $29,9 \%$ al total). 
Otro factor que parece determinante a la hora de exportar es si la empresa es a su vez importadora. Así, la práctica totalidad de las exportaciones $(96,6 \%)$ son realizadas por las empresas que exportan e importan al mismo tiempo.

La relevancia de la propiedad extranjera, la propiedad de filiales en el exterior y las importaciones entre las empresas exportadoras son, posiblemente, un indicador de su inserción en cadenas globales de valor.

En cuanto a la comparativa con otras economías de la UE, por tamaño en España sobresalen, tanto en número como en valor de sus exportaciones, las microempresas y en el extremo contrario, por el menor peso en número y en valor de las exportaciones, las grandes empresas. Las exportaciones medias de las empresas exportadoras españolas son inferiores a la media de la UE para todos los tamaños de empresa.

El análisis de las características de las empresas exportadoras es esencial para la eficacia de las políticas de apoyo a la internacionalización. La Estrategia de Internacionalización de la Economía Española 2017-2027 y sus sucesivos planes bienales de aplicación abundan en esta idea, al establecer como su primer eje de actuación la adaptación del apoyo a las necesidades y el perfil de la empresa. Ante los efectos económicos de la crisis sanitaria y el aumento de la incertidumbre en el escenario internacional, agudizado por fenómenos políticos, como la concreción del Brexit, la capacidad de adaptación de los instrumentos de apoyo a estos cambios debe intensificarse para acompañar con éxito a las empresas en su esfuerzo de internacionalización, tal y como se señala en el Informe de Evaluación del Plan de Acción para la Internacionalización de la Economía Española 2017-2018.

\section{Bibliografía}

Agencia Tributaria (varios años). Comercio exterior por características de la empresa. Departamento de Aduanas. https://www.agenciatributaria.es/ AEAT.internet/datosabiertos/catalogo/hacienda/ datos_estadisticos_Comercio_Exterior.shtml

Comisión Europea (2020) Eurostat. http://ec.europa. eu/eurostat/data/database

Instituto Nacional de Estadística (2020). Directorio Central de Empresas. https://www.ine.es/dyngs/ INEbase/es/operacion.htm?c=Estadistica $C \& c i d=1254736160707 \&$ menu $=u l t i D a t o s \& i-$ $\mathrm{dp}=1254735576550$

Secretaría de Estado de Comercio (varios años). Informes de Comercio Exterior. https://comercio. gob.es/ImportacionExportacion/ Informes_Estadisticas/

Secretaría de Estado de Comercio (2017). Estrategia de Internacionalización de la Economía Española 2017-2027. https://comercio.gob.es/es-es/ estrategia_internacionalizacion/Paginas/Estrategia-Internacionalizacion-2017-2027.aspx

Secretaría de Estado de Comercio (2019). Plan de Acción para la Internacionalización de la Economía Española 2019-2020. https://comercio. gob.es/es-es/estrategia_internacionalizacion/ Paginas/Plan-Accion-Internacionalizacion-201920.aspx

Secretaría de Estado de Comercio (2020). Informe de Evaluación del Plan de Acción para la Internacionalización de la Economía Española 20172018. https://comercio.gob.es/es-es/estrategia internacionalizacion/Paginas/informe-evaluacionplan-2017_18.aspx 


\section{ANEXO}

\section{ACLARACIONES METODOLÓGICAS}

La población objeto de estudio de los datos de Aduanas, según su publicación de Comercio exterior por características de la empresa, está constituida por las empresas que, habiendo declarado operaciones de comercio exterior, bien con países de la UE, bien con terceros países, figuren también en el año de referencia en el Directorio Central de Empresas (DIRCE), elaborado por el INE. Se trata, por tanto, de un ámbito más restringido que el de los operadores de comercio exterior.

Con respecto a los datos, deben realizarse las siguientes distinciones:

- Entre operadores y empresas del directorio de empresas.

- Entre comercio declarado y comercio total.

El término operador exportador es más amplio que el de empresa exportadora, ya que se incluye cualquier unidad que haya realizado al menos una operación de exportación, aunque no se trate necesariamente de una empresa, en el sentido amplio de este término. Los operadores de comercio declarado son aquellas unidades que, siguiendo la legislación vigente, han declarado al menos una operación de comercio exterior. La legislación impone obligaciones de declaración distintas según se trate de operaciones extracomunitarias (sistema Extrastat) o de operaciones intracomunitarias (sistema Intrastat).

En las operaciones con países terceros (Extrastat) está obligada a presentar la declaración aduanera toda persona física o jurídica que intervenga en actos a los que les sea de aplicación la legislación aduanera. Ello significa que toda operación de comercio exterior queda debida y puntualmente registrada en las correspondientes declaraciones aduaneras (a través del DUA, Documento Único Administrativo). Por tanto, en el sistema Extrastat, el comercio declarado se corresponde con el comercio total, salvo excepciones muy residuales derivadas de registros faltantes, retrasados o incompletos. Precisamente, es en las operaciones con terceros países donde puede haber un número más significativo de obligados a realizar la declaración aduanera que no tengan la consideración de empresa, por ejemplo, por envíos entre particulares que superen cierto valor.

Por su parte, en las operaciones intracomunitarias (sistema Intrastat), el obligado a presentar la declaración estadística Intrastat es la persona física o jurídica sujeta al impuesto sobre el valor añadido (IVA) que haya formalizado el contrato cuyo efecto sea la expedición o introducción de las mercancías y que haya superado el correspondiente umbral de exención (400.000 euros por flujo desde 2015 y de 250.000 euros entre 2008 y 2014). La existencia de este umbral de exención permite que aquellos operadores que realicen operaciones de ámbito intracomunitario por debajo del mismo no estén obligados a presentar las declaraciones Intrastat. De ahí que haya una parte de comercio que no se declara, pero que sí ha tenido lugar, y cuya estimación conforma la principal diferencia entre el comercio declarado y el $D$ 
comercio total. Existe un segundo elemento, aunque de menor cuantía, que corresponde a las operaciones intracomunitarias de operadores que, habiendo superado el umbral y, por tanto, habiendo dado lugar a la obligación de presentar las declaraciones Intrastat, no la hayan presentado. Para poder ofrecer estos componentes, Aduanas ha implantado un método de estimación robusto basado en las declaraciones recapitulativas de las operaciones intracomunitarias del IVA (modelo 349).

Con la elevación del umbral de exención hasta los 400.000 euros en 2015 se produce una ruptura de la serie ese año, ya que a partir de 2015 dejan de figurar como comercio declarado las operaciones intracomunitarias de aquellos operadores con expediciones entre los 250.000 y 399.999 euros para el caso de las exportaciones.

Eurostat, a diferencia de Aduanas, en la publicación de los datos para España, presenta los datos teniendo en cuenta el comercio total, es decir, incluyendo la estimación de comercio intracomunitario bajo umbral y la estimación de no presentación. Por ello, los datos de Eurostat para España, tanto en valor como sobre todo en número de exportadores o de empresas exportadoras, son superiores a los que ofrece Aduanas.

Los datos de los operadores, ya sean de comercio declarado o de comercio total, se cruzan con los del directorio de empresas generalmente a través del número de identificación fiscal. Aduanas cruza para España los datos de los operadores de comercio declarado con el DIRCE, mientras que Eurostat cruzará para cada país los datos de los operadores de comercio total con los directorios de empresas respectivos.

EI DIRCE es un registro de las empresas españolas que cubre todas las actividades económicas a excepción de la producción agraria y pesquera, los servicios administrativos de la Administración central, autonómica y local (incluida Seguridad Social), las actividades de las comunidades de propietarios y el servicio doméstico. Por ello, no cruzarán con el DIRCE ni las empresas extranjeras (sin establecimiento en España) que realicen exportaciones desde España, ni las empresas de las actividades económicas excluidas. En ambos casos, se trata de un número reducido de empresas, si bien en el caso de las empresas extranjeras pueden realizar exportaciones por importes significativos.

Fuente: elaboración propia. 
